Research article

\title{
Late Quaternary nearshore molluscan patterns from Patagonia: Windows to southern southwestern Atlantic-Southern Ocean palaeoclimate and biodiversity changes?
}

\author{
M.L. Aguirre ${ }^{\mathrm{a}, \mathrm{b}, *}$, S. Richiano ${ }^{\mathrm{a}, \mathrm{c}}$, A.H.L. Voelker $^{\mathrm{d}, \mathrm{e}}$, D.L. Dettman ${ }^{\mathrm{f}}$, B.R. Schöne ${ }^{g}$, H.O. Panarello ${ }^{\mathrm{a}, \mathrm{h}}$, \\ M. Donato ${ }^{\mathrm{a}, \mathrm{b}, \mathrm{i}}$, L. Gómez Peral ${ }^{\mathrm{b}, \mathrm{j}}$, L.E. Castro $^{\mathrm{k}}$, R. Medina ${ }^{1, \mathrm{~m}}$ \\ ${ }^{a}$ CONICET, Consejo Nacional de Investigaciones Científicas y Técnicas, Argentina \\ ${ }^{\mathrm{b}}$ Facultad de Ciencias Naturales y Museo (FCNyM), Universidad Nacional de La Plata (UNLP), 1900 La Plata, Argentina \\ ${ }^{\mathrm{c}}$ Instituto Patagónico de Geología y Paleontología (CONICET-CENPAT), Boulevard Brown 2915, Puerto Madryn, Chubut, Argentina \\ d Divisão de Geologia e Georecursos Marinhos, Instituto Português do Mar e da Atmosfera (IPMA), Avenida Doutor Magalhães Ramalho 6, 1495-165 Alges, Portugal \\ e Centre of Marine Sciences (CCMAR), Universidade do Algarve, Campus de Gambelas, 8005-139 Faro, Portugal \\ ${ }^{\mathrm{f}}$ Environmental Isotope Laboratory, Department of Geosciences, University of Arizona, Tucson, AZ, USA \\ ${ }^{\mathrm{g}}$ Institute of Geosciences, University of Mainz, Germany \\ ${ }^{\mathrm{h}}$ Instituto de Geocronología y Geología Aplicada, CONICET-UBA, Buenos Aires, Argentina \\ ${ }^{\mathrm{i}}$ Instituto de Limnología "Raúl A. Ringuelet", CONICET-FCNYM, La Plata, Argentina \\ ${ }^{\mathrm{j}}$ Centro de Investigaciones Geológicas, CONICET-UNLP, Diag. 113 esq. 64, 1900 La Plata, Argentina \\ ${ }^{\mathrm{k}}$ Cátedra de Geoestadística, FCNyM (UNLP), Argentina \\ ${ }^{1}$ Departamento de Ciencias Geológicas, Facultad de Ciencias Exactas y Naturales, Universidad de Buenos Aires, Buenos Aires, Argentina \\ ${ }^{\mathrm{m}}$ Departamento de Agrimensura, FI, Universidad de Buenos Aires, Buenos Aires, Argentina
}

\section{A R T I C L E I N F O}

\section{Keywords:}

Pleistocene

Holocene

P. antiqua

T. atra

Palaeoproductivity

ocean fronts

Mar Argentino

\begin{abstract}
A B S T R A C T
Varied approaches (palaeobiodiversity, palaeobiogeography, bioerosion, geochemistry) to unique Patagonian late Quaternary molluscan assemblages in the southwestern Atlantic, with ages especially from interglacial Marine Isotope Stage (MIS) 5e and MIS 1, provide large-scale and long-temporal palaeoenvironmental data for the southern SWA. Together with new patterns of $\delta^{18} \mathrm{O}$ and $\delta^{13} \mathrm{C}$ variations in modern, mid-Holocene, and Late to Middle Pleistocene shells of Protothaca antiqua (Bivalvia) and the coeval Pleistocene Tegula atra (Gastropoda), the overall sources of evidence illustrate possible responses to recent palaeoclimate and sea-ice changes around the southernmost SWA-western Antarctica, leading to modern conditions. For the mid-Holocene, the influence of the Hypsithermal is confirmed. In the northern Golfo San Matías, the highest $\delta^{18} \mathrm{O}$ and $\delta^{13} \mathrm{C}$ values support higher salinity and sea surface temperatures (SST), and a Golfo San Matías Front stronger than today. Lower $\delta^{18} \mathrm{O}$ values in the northern Golfo San Jorge (GSJ) compared to the Late to Middle Pleistocene suggest warmer mid-Holocene waters, independently supported by thermally anomalous molluscan taxa, geographical shifts of areas of endemism and absence of T. atra (cold water proxy); overall higher $\delta^{13} \mathrm{C}$ values compared to present suggest higher productivity. For the Late to Middle Pleistocene (particularly MIS 5e), highest $\delta^{13} \mathrm{C}$ values (relative to modern and mid-Holocene trends) match with the location of tidal fronts and areas of maximum chlorophyll-a concentrations today. Accordingly, these fronts may have been already active and significantly intensified due to the prevailing climate conditions that included colder waters and stronger upwelling from the southern GSJ southwards. This is independently supported by palaeobiogeographical and bioerosion trends and the dominance of the cold water species T. atra during the Pleistocene, which is dispersed from the SE Pacific
\end{abstract}

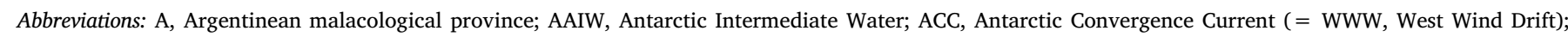

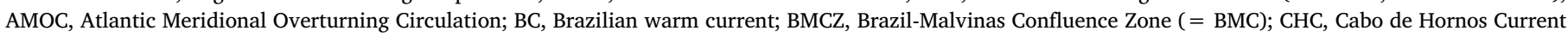

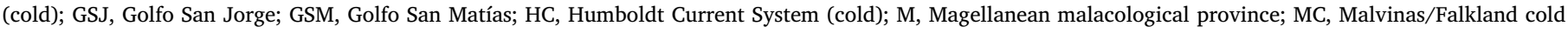

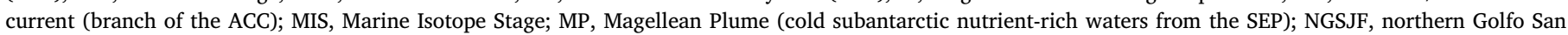

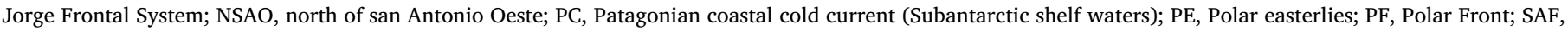

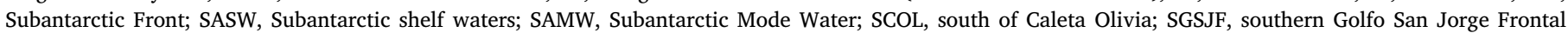
System; SO, Southern Ocean; SST, sea surface temperature; SSW, southern westerly winds

* Corresponding author at: CONICET and Facultad de Ciencias Naturales y Museo (FCNyM), Universidad Nacional de La Plata (UNLP), Laboratorio 6, calle $64 \mathrm{~N}^{\circ}$ 3, 1900 La Plata, Argentina.

E-mail address: maguirre@fcnym.unlp.edu.ar (M.L. Aguirre).
} 
into the SWA by rafting on kelps and whose occurrence is controlled by SST, light, winds, and nutrient concentration/productivity. Repeated, abrupt climate oscillations during the last glacial cycle with significant impact on SST, ice melting and surface-ocean stratification in the western Antarctica-Weddell Sea-Antarctic Circumpolar Current realm are so far the only available plausible explanations to account for the different midHolocene and modern patterns, and for the regional disappearance of T. atra after MIS 5e. Further palaeoceanographic research in this key area is needed to understand how all these mechanisms operated in the past, potentially influencing the Patagonian shelf waters and coastal fronts.

\section{Introduction}

Patagonia is the only large landmass in the southern hemisphere south of ca. $40^{\circ} \mathrm{S}$, which contains numerous broad-scale Quaternary palaeoenvironmental/palaeoclimate records (e.g., Garreaud et al., 2013). In particular, the Patagonian coastal area (Argentina) in the southwestern Atlantic (SWA), located at a passive margin near the Drake Passage and western Antarctica (Fig. 1A), exhibits spectacular and unique Quaternary molluscan-rich marine deposits (Fig. 1B-I, 2), nowhere else so extensively abundant and well preserved in South America, formed by high sea-level episodes during interglacials of the Middle to-Late Pleistocene (Marine Isotope Stage (MIS) 11, 9, 7 and 5) and during the mid-Holocene (throughout the manuscript we use midHolocene in a broad sense and not as reference to the stratigraphic epoch) (MIS 1) (Lisiecki and Raymo, 2005; Aguirre et al., 2011; Gibbard and Lewin, 2016; Düsterhus et al., 2016; Head et al., 2017) (Appendixes A.1, A.2). Earlier highstands (pre-MIS 11) are preserved further inland, but their molluscan content is either scarce and/or highly abraded or completely unpreserved. Unique oceanographic and environmental conditions characterize the southern SWA, the only area of the southern hemisphere where a permanent injection of cold, nutrient-rich subpolar waters extend beyond $40^{\circ} \mathrm{S}$ (Gersonde and Zielinski, 2000; Piola et al., 2018; Franco et al., 2018; Combes and Matano, 2018). Influenced by three of the largest thermal fronts of the world oceans (Subtropical/ Subantarctic/ Polar) and high chlorophyll-a concentrations along a variety of local oceanic fronts (Acha et al., 2004; Acha, 2015; Piola et al., 2018), this sector of the South Atlantic-Southern Ocean represents a key area to investigate modern and past atmospheric-oceanic changes (Bianchi et al., 2005; Anderson et al., 2009; Buizert and Schmittner, 2015; Yao, 2017; Panassa et al., 2018). Overall, this setting offers an unmatched opportunity to study potential linkages between littoral Late Quaternary molluscan assemblages and physical/biotic features of the southern SWA at a macrogeographical scale during the most recent climatic cycles.

Furthermore, in marine settings of the southern hemisphere, palaeoclimate/paleoceanographical records linked to Late Quaternary climate oscillations are less well known than those of the Northern Hemisphere (e.g., Lisiecki et al., 2008; Yin and Berger, 2015). This difference applies especially to the context of the Southern Ocean (i.e., south of $50^{\circ} \mathrm{S}$, encircling Antarctica, including subantarctic regions and the southern parts of the South Atlantic, South Pacific and Indian oceans; Koubbi et al., 2014). Current knowledge from this region includes qualitative or quantitative data sets derived from a variety of disciplines and approaches, ranging from characterizations of modern abiotic and biotic features, geological and oceanographical aspects, climate and palaeoclimate models (e.g., Hodell et al., 2002; Wefer et al., 2003; Cortese et al., 2007; Clark, 2014; Roberts et al., 2017; Anderson et al., 2018; Saunders et al., 2018; Brook and Buizert, 2018; Combes and Matano, 2018). However, while most contributions are focused on the open or deep ocean, there are notably fewer nearshore records, particularly from the southern SWA, whose thermal evolution and that of the adjacent continents are still not fully understood (Bianchi and Gersonde, 2002; Hodell et al., 2003; Gersonde et al., 2005; Chiessi et al., 2015; Voigt et al., 2015, 2016; Howe et al., 2016).

Coastal marine palaeoclimate records are essential to increase our understanding of ocean-atmospheric climate dynamics (Harley et al.,
2006). Even when continental shelves represent only a minor percentage of the total ocean, they hold an important fraction of the global carbon reservoir, and contribute significantly to global marine primary production and dissolved organic carbon (Dai et al., 2012; Bauer et al., 2013; Bianchi et al., 2005, 2009; Carreto et al., 2016), factors that can strongly respond to climate changes. Regional trends of biotic responses to climate change from nearshore settings can help to delineate potential future impacts of sea-surface temperature (SST) and circulation changes (Maslin and Swann, 2006; Gruber, 2015), considering that coastal marine systems are expected to be strongly affected by future increases in atmospheric $\mathrm{CO}_{2}$ (increasing temperature by ca. $2{ }^{\circ} \mathrm{C}$ in the next 100 yrs.) (Walther et al., 2002; Bernhardt and Leslie, 2013). Coastal data on past sea-levels can also provide complementary information linked to ice sheet dynamics during deglaciations (Dutton et al., 2015), still poorly understood in the area of southernmost Patagonia-Western Antarctica, particularly in relation to the impact that icebergs, subglacial meltwater and iceberg/meltwater macro and micronutrient inputs have on total Southern Ocean productivity (e.g., Death et al., 2014; Hansen et al., 2016; Henley et al., 2017; Paparazzo and Esteves, 2018).

Specifically, regarding records from late Quaternary coastal deposits of Argentina, we also note that palaeoclimatic interpretations are scarce and have so far been contradictory. One example can be seen in SST conditions during the mid-Holocene (MIS 1) in a broad sense and the Last Interglacial (MIS 5e). Based on molluscan evidence, some authors argued for a warmer-than-present mid-Holocene Climatic Optimum (Hypsithermal), while others have contradicted this conclusion or reported warming in isolated localities only - mostly in the northern (Bonaerensian) sector (Fig. 1). In addition, during the Last Interglacial, similar, warmer-or-colder-than-present surface waters have been postulated (Feruglio, 1950; Aguirre, 1993; Aguirre et al., 2011, 2017).

In the present study, we reexamine Late Quaternary molluscan remains from the Patagonian coastal area, between San Antonio Oeste

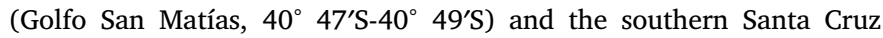
province $\left(49^{\circ} 20^{\prime} \mathrm{S}\right.$ ) (Figs. $\left.1 \mathrm{~A}, 2\right)$, to interpret eventual palaeoclimate changes relative to the present based on various sources of evidence. Based on shell $\delta^{18} \mathrm{O}$ and $\delta^{13} \mathrm{C}$ variations of Protothaca antiqua (King) (Bivalvia), collected from Late to Middle Pleistocene, mid-Holocene and modern Patagonian nearshore strata (Fig. 1B-F), and of the coeval Pleistocene Tegula atra (Lesson) (Gastropoda) (Fig. 1G-I), in combination with palaeobiodiversity, palaeobiogeographical and bioerosion trends (Aguirre et al., 2011, 2013, 2017; Richiano et al., 2013, 2015, 2017), we aim to investigate how SST and productivity levels in the Pleistocene (especially MIS 5e) and mid-Holocene (MIS 1) compare to today along the Patagonia coast and whether general patterns can be linked to climate changes and coastal fronts. Particular questions to be addressed are: 1) Were Late to Middle Pleistocene interglacial surface oceanic waters in Patagonia colder or warmer than during the midHolocene and today?; 2) Was Last Interglacial productivity higher or lower relative to the mid-Holocene and present day?; 3) How do SST and productivity compare in the Mid-Holocene relative to today along the Patagonia coast?; 4) Could the overall molluscan patterns be linked to biological responses to ocean fronts? Finally, we hypothesize that overall trends, geographically and through time, could be responses to different ocean-atmospheric conditions; alternatively, no objective distinction is possible. 


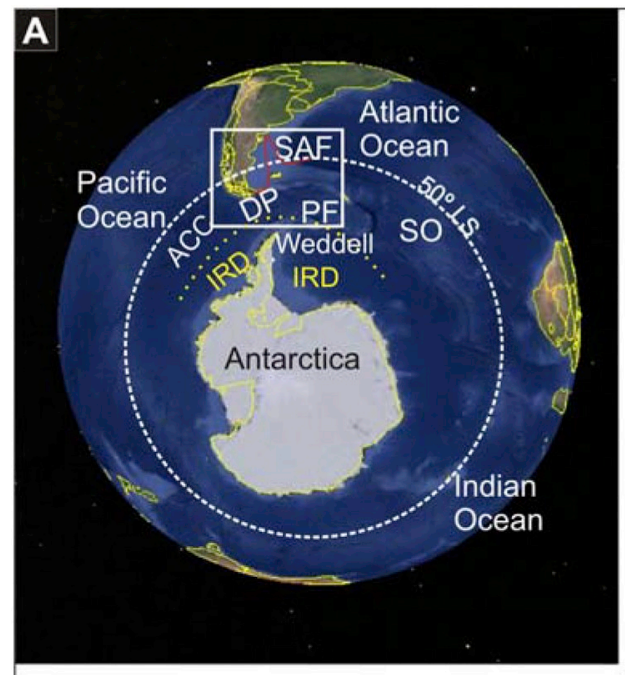

Patagonian localities sampled:

Puerto Lobos $=$ Northern Patagonia Camarones $=$ Central Patagonia

Puerto Deseado $=$ Southern Patagonia

* samples analyzed at University of Mainz (all others at University of Arizona)

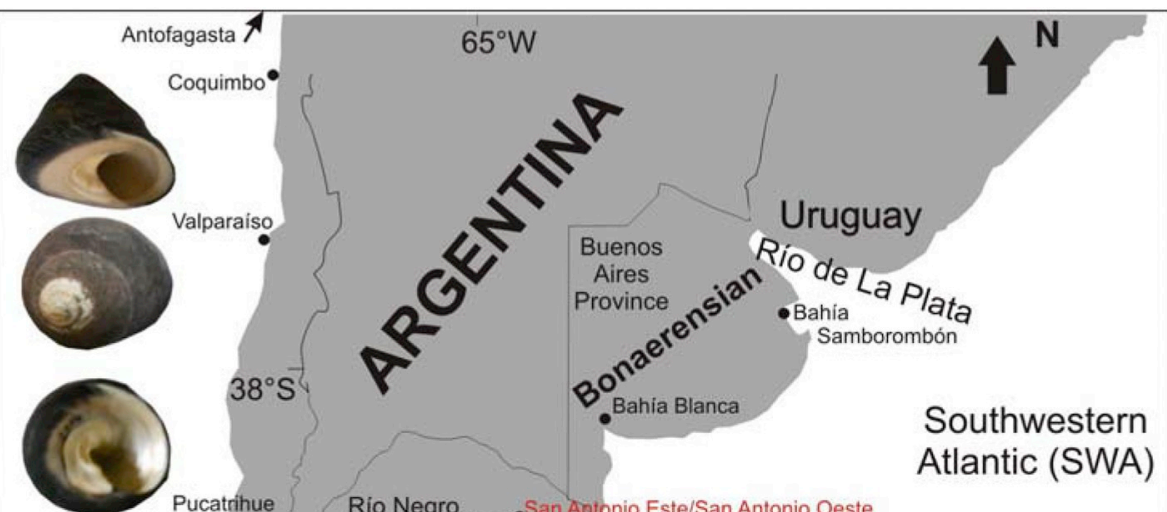

Tegula atra

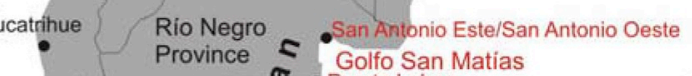

Atlantic (SWA)

$$
\text { (1) }
$$
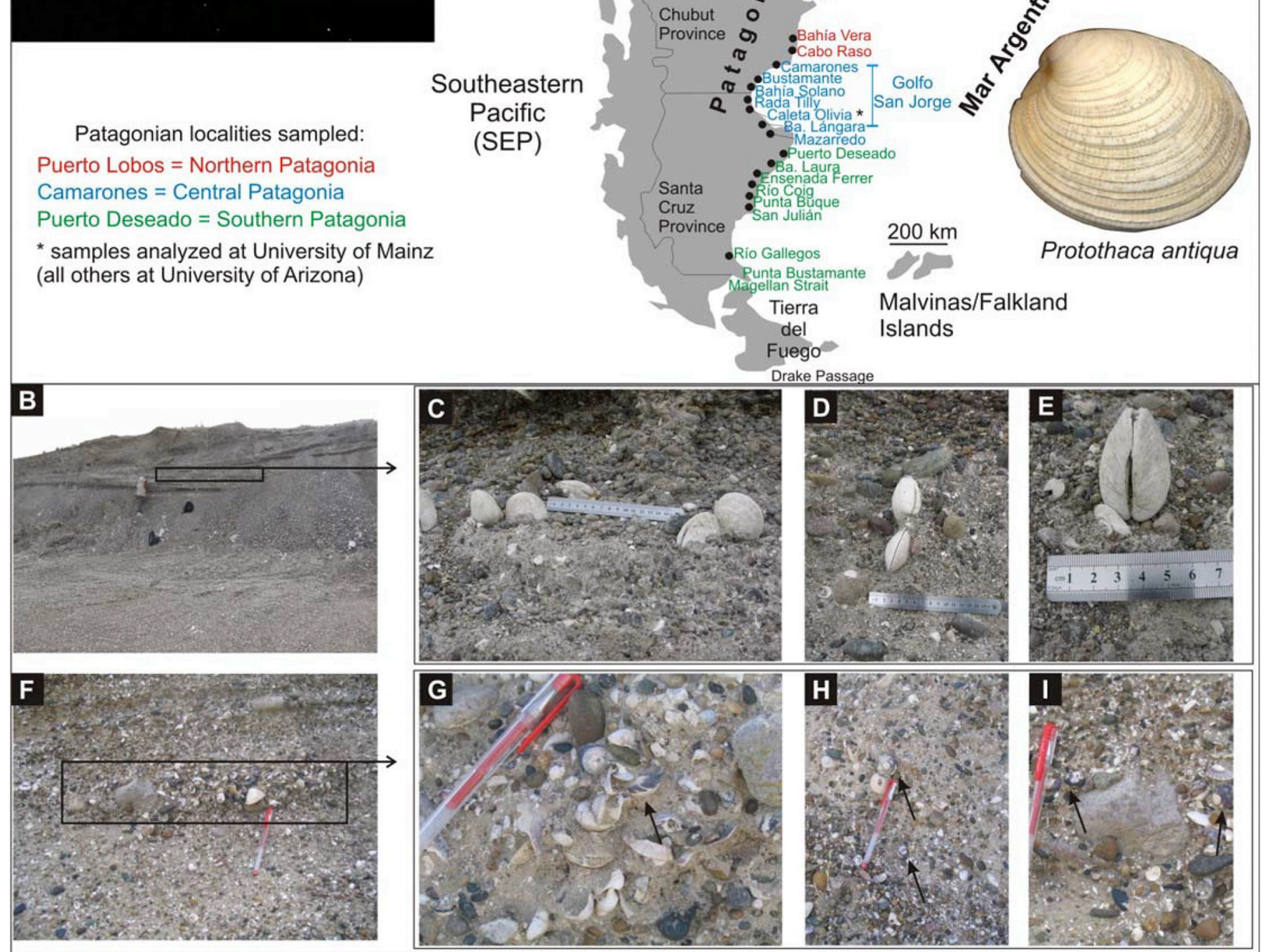

Fig. 1. Study area, Patagonia, Argentina, on the southwestern Atlantic margin (Mar Argentino, South America, Southern Hemisphere). This climatically important region is located near the Southern Ocean (SO), Polar Front (PF), Drake Passage, and western Antarctica under the influence of ice-rafted debris (IRD; sensu Maslin and Swann, 2006). (A): Location of areas containing well preserved Late Quaternary shell-rich coastal deposits in Argentina. Main sites sampled in northern, central and southern Patagonian coastal sectors (e.g., red = Northern Patagonia; blue = Central Patagonia; green = Southern Patagonia). * = samples analysed at University of Mainz; the rest at University of Arizona. Molluscs analysed: Protothaca antiqua (Bivalvia, Venerida; Patagonian localities) and Tegula atra (Gastropoda, Trochoidea; Patagonian Late Pleistocene localities between Puerto Lobos and Golfo San Jorge, and modern sites along the Southeastern Pacific coast of Chile; note that this species became extinct from the southwestern Atlantic in the Holocene). (B-I): field observations. Preservation examples of Protothaca antiqua, in some cases with jointed valves and in life position (C, D, E) and Tegula atra (F, G, H, I) (often mistaken by by gravels/pebbles, e.g., H, I) within Late Quaternary marine terraces along Patagonia. (For interpretation of the references to colour in this figure legend, the reader is referred to the web version of this article.) 

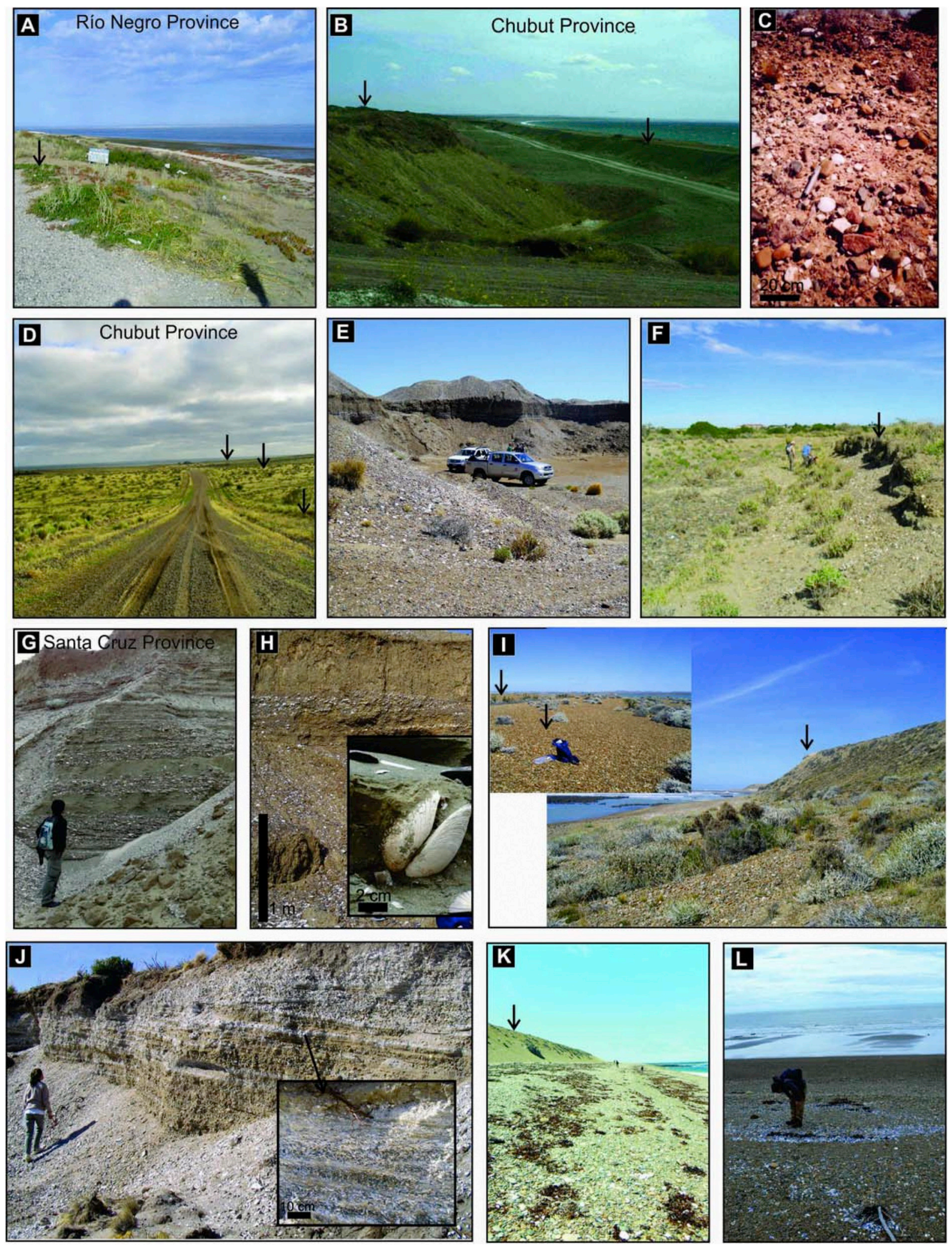

(caption on next page) 


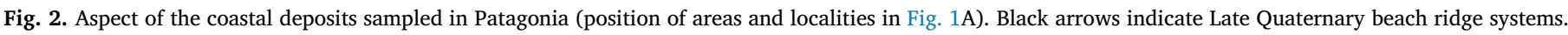

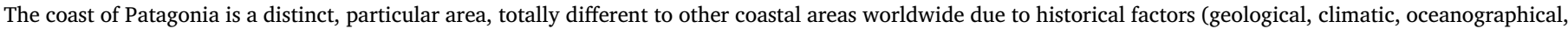

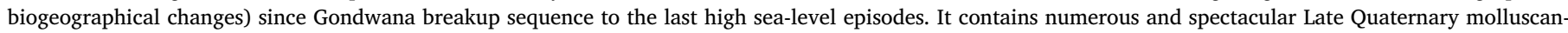

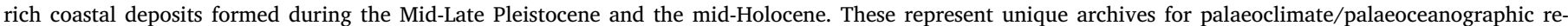

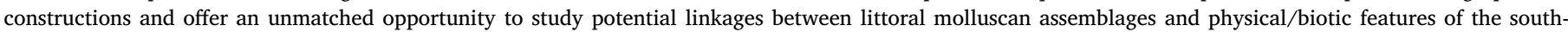

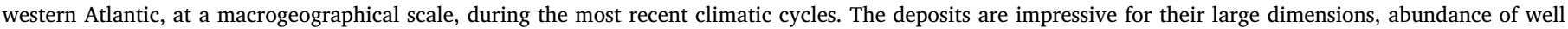

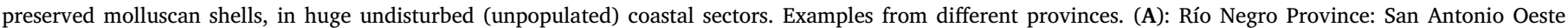

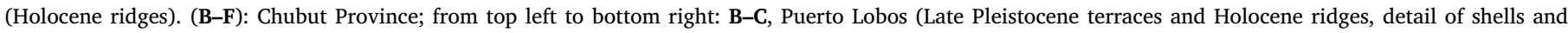

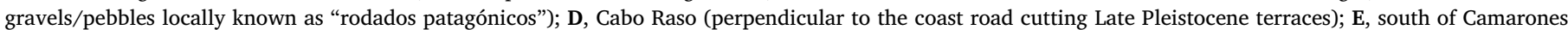

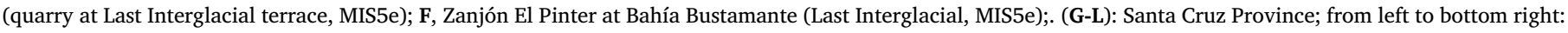

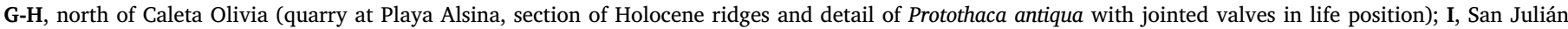

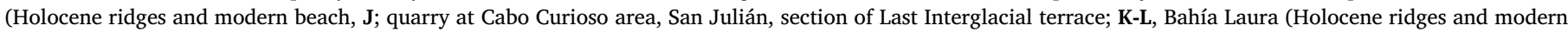
beach). Dating and estimated elevation above present mean sea-level of the deposits available elsewhere (references in Appendixes A.1, A.2).

\section{Background: deposits and target species, modern Patagonian littoral setting, a southern SWA key area}

\subsection{Coastal deposits and target species}

In Patagonia, mollusc-rich deposits occur almost continuously along $>1200 \mathrm{~km}$ (Río Negro, Chubut and Santa Cruz provinces) (Fig. 1A). These outcrops comprise beach ridges, marine terraces and estuarine deposits, Mid-Pleistocene (MIS 11) to Holocene (MIS 1, "midHolocene" in a broad sense) in age, locally known as "Marine Terraces" (MT), so-called MT IV, V and VI sensu Feruglio (1950) (Figs. 1B-I, 2A-L). They extend from the modern supratidal zone to a few (5 to 10) kilometers inland. General geomorphological-geochronological and palaeoinvertebrate descriptions are available elsewhere (Aguirre et al., 2008; Ribolini et al., 2011; Pappalardo et al., 2015) (Appendix A.1, A.2) as well as evolutionary models (Ponce et al., 2011; Medina et al., 2014; Mouzo, 2014) which altogether provide the basic framework for interdisciplinary approaches in the area and the time slices considered. We want to point out, however, that although dating uncertainties exist, especially regarding to the oldest marine deposits (Appendix A.2, Table A.2a, b and references therein), they have no effect on our interpretations of the Late to Middle Pleistocene interglacial terraces (MIS 9-1). In these deposits two ubiquitous, emblematic molluscan species, with different life modes but similar feeding strategies, are relevant for palaeoclimate/palaeoceanographical interpretations: $P$. antiqua (King, 1832) and T. atra (Lesson, 1830).

P. antiqua (assigned by other authors either to Venus, Ameghinomya, Chione, Leukoma) (Worms) is the most common and widely distributed mollusc of the marine Quaternary of Patagonia, where it occurs at least since ca. MIS 11 (ca. $400 \mathrm{ky}$ ). It is infaunal, commonly inhabiting soft substrates (sandy to silty bottoms) of the lower intertidal and shallow infralittoral zones (preferentially down to ca. $30 \mathrm{~m}$ water depth), and a suspension-feeder (consumer of all plankton available). It is highly adapted to cold temperate waters $\left(6\right.$ to $14^{\circ} \mathrm{C}$ ) and the cold waters of subantarctic origin $\left(2-10^{\circ} \mathrm{C}\right)$. It lives in the Magellanean malacological province along the SWA and Southeastern Pacific (SEP), a geographical range controlled by the cold Humboldt Current System and the Cabo de Hornos cold current in the SEP, and, in the SWA, by the cold Malvinas/ Falkland current (MC), a branch of the Antarctic Circumpolar Current (ACC) or West Wind Drift, and the coastal Patagonian current (PC), which transports subantarctic waters from the SEP via the Magellan Strait and Le Maire Strait into the SWA (Franco et al., 2018) (Figs. 1A, 3C). P. antiqua feeds on algae-phytoplankton and zooplankton (EscatiPeñaloza, 2005). The shell is aragonitic and consists of an outer prismatic shell layer, a crossed-lamellar middle shell layer, and an inner homogeneous layer, with locally developed organic-rich components (Lazareth et al., 2006) (A.3). Since it grows during the whole year, $\delta^{18} \mathrm{O}_{\text {shell }}$ records nearly the full seasonal temperature amplitude, whereby growth rate is fastest in October-November linked to the availability of fresh phytoplankton on which it feeds (Rubo et al., 2018) (maximum phytoplankton blooms in austral Spring; Bianchi et al., 2005; Romero et al., 2006; Franco et al., 2008; Carreto et al., 2016).
T. atra is the dominant gastropod during the Late to Middle Pleistocene in Patagonia, between Golfo San Matías (south of San Antonio Oeste) and the southern Santa Cruz province, and occurs within deposits assigned to MIS 9e (ca. $325 \mathrm{ky}$ ), MIS 7c (ca. $225 \mathrm{ky}$ ) and particularly MIS 5e (ca. $125 \mathrm{ky}$ ). It is absent in MIS 11 (400 ky), the warmest and longest late Quaternary interglacial in South America (Burckle, 1993; Ortlieb et al., 1996), and in the Holocene (MIS1) including the present. It does not live today in the adjacent Patagonian ocean (Mar Argentino) or anywhere else in the SWA. It is a common SEP species living in cold waters $\left(2-8{ }^{\circ} \mathrm{C}\right)$ along the Humboldt and Cabo de Hornos currents (Fig. 3C), between southern Perú and southern Chile and - unconfirmed- in western Antarctica. It is a mobile epifaunal, herbivorous species feeding on algae and phytoplankton in highly productive waters, is very common mostly in the intertidal zone on hard and rocky bottoms, and is typically dispersed by passive rafting on brown macroalgae (kelps) (i.e., Durvillaea antarctica) (Aguirre et al., 2013; López et al., 2017), which share its same modern range. Apart from light, winds, and nutrient concentration/productivity, temperature is a most critical controlling factor for growth, flotation and survival of $D$. antarctica and of T. atra in the SEP (Tala et al., 2016); a ca. $1{ }^{\circ} \mathrm{C}$ rise of temperature has lethal physiological consequences for $\mathrm{Te}$ gula (Stenseng, 2005 in Aguirre et al., 2013). No studies of its shell microstructure or sclerochronology exist so far. In other, similar Vetigastropoda, the aragonitic shell is made of an outer, crossed or crossedlamellar and an inner nacreous shell layer (A.3).

\subsection{Modern Patagonian littoral setting}

Belonging to the Mar Argentino, Patagonia has been described in terms of physical conditions (e.g., SST, salinity, winds, currents, ocean fronts, substrate nature) and biological features (e.g., chlorophyll-a, nutrient availability) (Combes and Matano, 2018; Franco et al. García et al., 2018; Piola et al., 2018, and references therein) (Figs. 3, 4). The Patagonian continental shelf (ca. $41-55^{\circ} \mathrm{S}$ ) extends as part of the southwestern Atlantic shelf $\left(23^{\circ}\right.$ to $55^{\circ} \mathrm{S}$; largest in the southern hemisphere) along $>1500 \mathrm{~km}$ from the Golfo San Matías to the Drake Passage (Fig. 1A) and exhibits the widest and most gentle relief worldwide (Palma et al., 2004a,b, 2008; Piola and Falabella, 2009). The circulation pattern is characterized by two northwards flowing cold currents, the coastal PC and the MC, together with the seasonal Brazil-Malvinas Confluence (BMCZ) (Fig. 3C). South of $40^{\circ} \mathrm{S}$ the mean circulation is dominated by a general northeastward flow controlled by the discharges from the Magellan Straits, tidal mixing, wind forcing, and the offshore influence of the MC (Palma et al., 2008).

According to salinity, four water masses have been identified: coastal water (low salinity, < 33.4), shelf water or midshelf water (33.4 to 33.8), Malvinas water ( $>33.8$ ), and high salinity coastal waters around the Golfo San Matías (Bianchi et al., 2005). SST ranges from 10 to $18{ }^{\circ} \mathrm{C}$ in summer and ca. 2 to $10^{\circ} \mathrm{C}$ in winter (Baldoni et al., 2015). The Patagonian shelf is one of the highest productivity regions of the world ocean; apart from the thermal subtropical and subantarctic fronts (Figs. 1A, 3C), a number of local ocean fronts (salinity, thermal, tidal, 


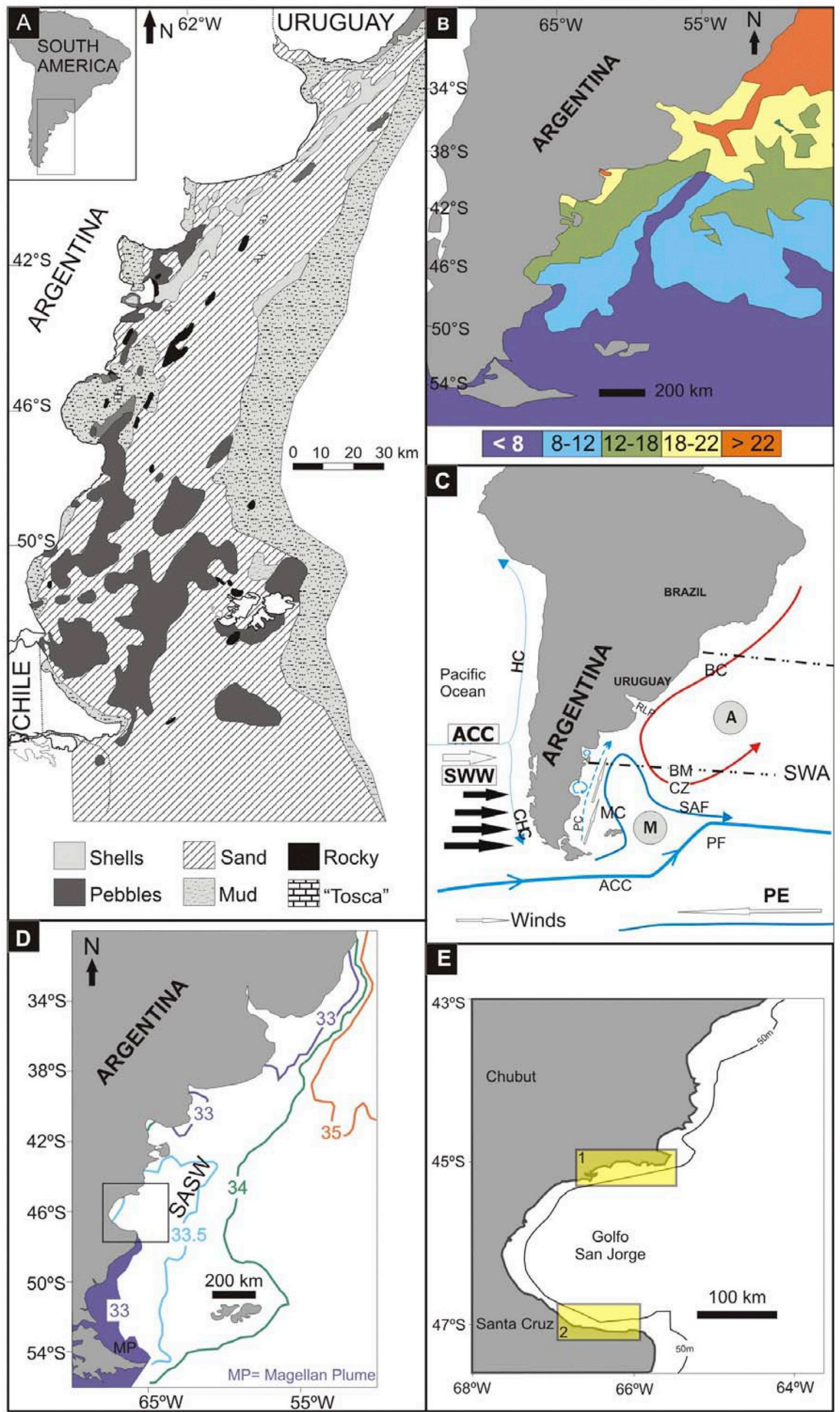

Fig. 3. Physical features of the Patagonian nearshore and Mar Argentino (sector shown with an inserted rectangle in A) (modified from Aguirre et al., 2013; Richiano et al., 2017. (A): substrates (modified from Parker et al., 1997). (B): Sea surface temperature (SST, ${ }^{\circ} \mathrm{C}$ ) (modified from, Piola and Falabella, 2009; Piola et al., 2010; other references therein). (C): Ocean circulation. southwestern Atlantic (SWA): BC, Brazilian warm current; MC, Malvinas/Falkland cold current (branch of the ACC); PC, Patagonian coastal cold current (Subantarctic shelf waters); ACC, Antarctic Circumpolar Current; BMCZ, Brazil-Malvinas Confluence Zone; SAF, Subantarctic Front; PF, Polar Front; ACC, Antarctic Circumpolar Current; SSW: southern westerly winds; PE: Polar easterlies; arrows indicate direction of winds (darker arrows correspond to maximum wind speeds). In the Southeastern Pacific: CHC, Cabo de Hornos Current; HC, Humboldt Current; WWW, West Wind Drift $=$ Antarctic Convergence Current (ACC); information taken from Acha et al., 2004; Bianchi et al., 2005; Palma et al., 2008, Piola and Falabella, 2009; Glembocki et al., 2015; Olguín-Salinas et al., 2015; Ruiz-Etcheverry et al., 2016; Kahl et al., 2017; Piola et al., 2018; Combes and Matano, 2018; Franco et al., 2018; other references therein and in A.6). Biogeographical regions: A, Argentinean malacological province; M, Magellanean malacological province. (D): salinity gradients (\%o), Magellan Plume (cold subantarctic nutrient-rich waters from the SEP). Rectangle corresponds to the area of Golfo San Jorge shown in E. (E): 1, northern Golfo San Jorge Frontal System (NGSJF), 2, southern Golfo San Jorge Frontal System (SGSJF) (modified from Glembocki et al., 2015). Note that the Subtropical (BMCZ), Subantarctic (SAF) and Polar Front (PF) are among the largest thermal fronts in the world ocean (Acha, 2015). In the Southern Ocean, Deep water formation (downwelling) takes place around Antarctica (Weddell Sea, Ross Sea); upwelling occurs around Antarctica in the Antarctic Divergence Zone along the (ACC), and within the SWA mainly along the Shelf-break front and at the BMCZ (BCMC Intertropical Zone); carbon storage occurs around the northern flank of the ACC and in Patagonia mainly along the shelf-break front (e.g., Gruber, 2015; Kahl et al., 2017). middle shelf, shelf-break) exhibit high chlorophyll-a concentrations due to phytoplankton photosynthetic activity, which affects all levels of the trophic chain, including benthic molluscan communities (Romero et al., 2006; Carreto et al., 2007; Franco et al., 2008; Rivas and Pisoni, 2010;
Paparazzo et al., 2010; Acha, 2015).

The main substrates (Parker et al., 1997) are composed of coarse to medium sands and pebbles ("Rodados patagónicos", by some interpreted as a product of transport from the Andean region during 


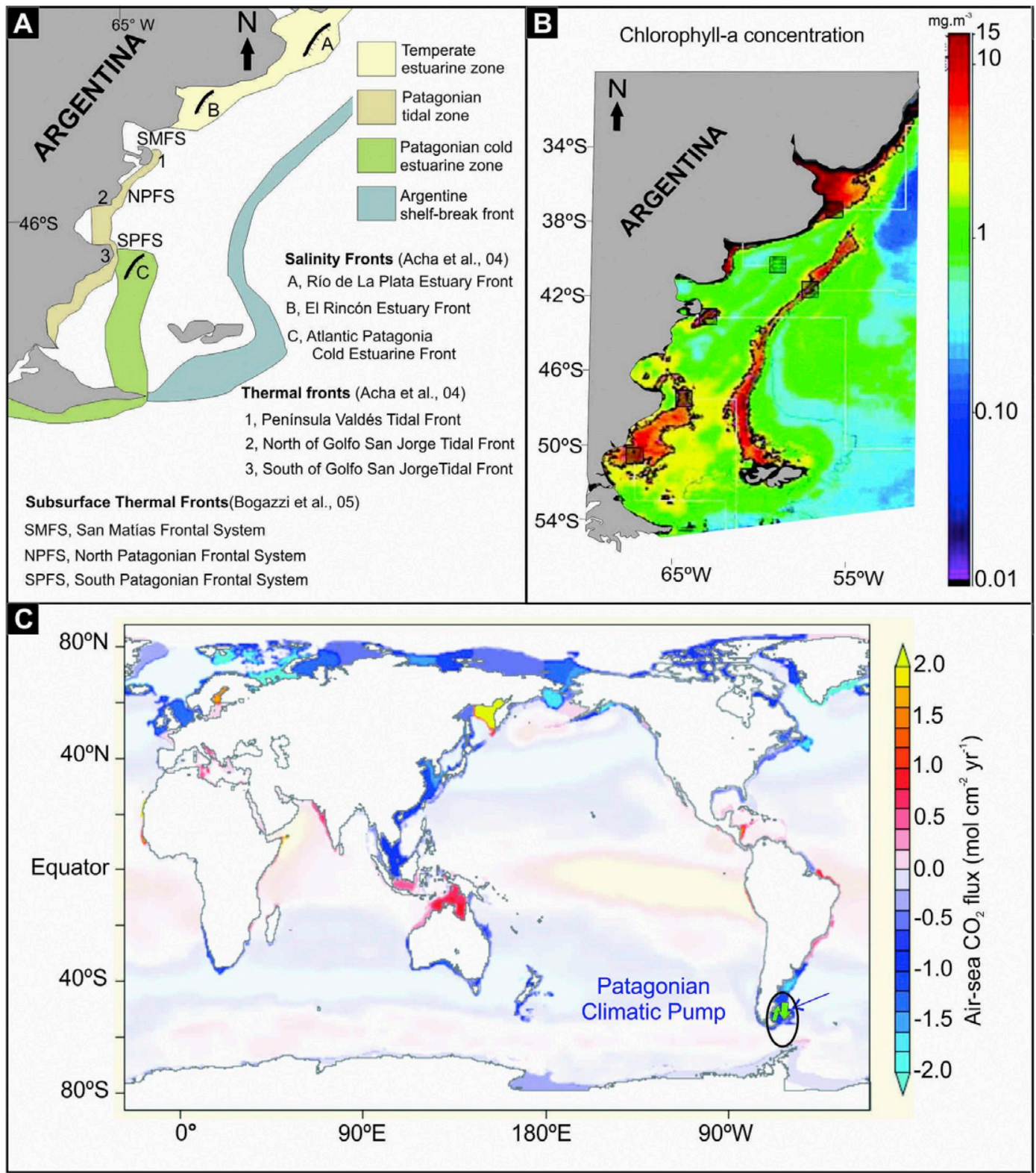

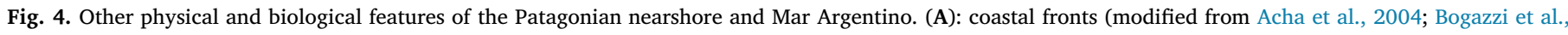

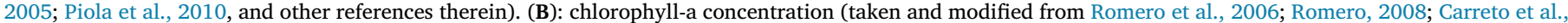

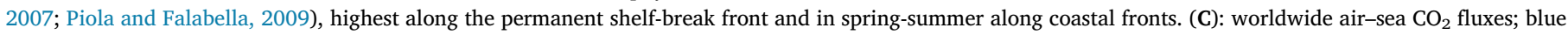

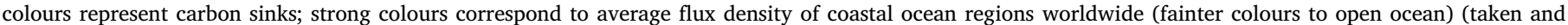

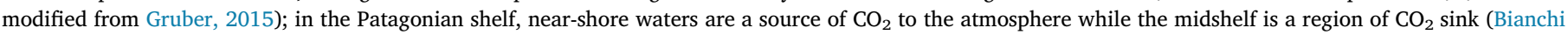

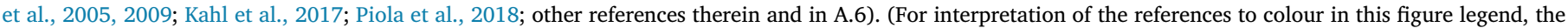
reader is referred to the web version of this article.)

Pleistocene deglaciations; Martínez and Kutschker, 2011), although fine silts and clays can locally occur.

\subsection{Relevance of the southern SWA: key area for regional palaeoclimate and palaeoceanographical interpretations}

The southern SWA, as part of the Southern Ocean and near western Antarctica (with its unique nature of a sea ice zone; Maksym et al., 2012), is a complex oceanic and relevant geographical area to target, due to its essential role in global ocean circulation and climate regulation through the thermohaline system, determined by upwelling and downwelling forces (e.g., Toggweiler and Samuels, 1995; Buizert and Schmittner, 2015), and late Quaternary palaeoceanographical interpretations (e.g., Boyle, 2000; Sachs and Anderson, 2005; Kaiser et al.,
2005; Wolff et al., 2006; Graham et al., 2015; Turney et al., 2017). The so-called Atlantic Meridional Overturning Circulation (AMOC) plays a key role in climate variability through northward transport and storage of heat, lower salinity water and carbon (Peterson and Stramma, 1991; Garzoli and Matano, 2011; Marshall and Speer, 2012; Talley, 2013). In western Antarctica, deep waters are formed in the Weddell Sea where downwelling allows deep ocean ventilation. Strong upwelling of deep nutrient-rich waters occurs in the Antarctic Divergence Zone along the polar front. The Antarctic Convergence Zone in the northern flank of the ACC near the subantarctic front, in particular, is one source of Antarctic Intermediate Water (AAIW), a return branch of the AMOC, and of Subantarctic Mode water (SAMW) (Pahnke and Zahn, 2005; Hartin et al., 2011; Yao, 2017; Franco et al. García et al., 2018), and is critical for productivity-related circulation (Jong et al., 2012; Death 
et al., 2014; Paparazzo and Esteves, 2018).

The southern SWA also holds the maximum speed of the southern westerlies wind belt (SWW, ca. 49-53 S; Fig. 3), with highest surface ocean current speeds at the subantarctic and polar fronts and at the boundary of the ACC-Weddell Gyre (just south of the mid-ocean ridge near $55^{\circ} \mathrm{S}$ ) (Toggweiler et al., 2006; Kilian and Lamy, 2012; Fletcher and Moreno, 2012) (Figs. 1A, 3, 4). The wind-driven ACC has been of global importance since its formation, but especially during the last climatic cycles when modulation of its intensity and by extension of the MC transport along the Argentinean Shelf-Break Front (Toggweiler et al., 2006; Combes and Matano, 2018) also impacted marine food webs and ecosystems (Muller-Karger et al., 2017; Wiebe et al., 2017).

Most importantly, large atmospheric carbon storage (through phytoplankton photosynthetic activity) takes place in the outermost boundary of the Southern Ocean, and along Patagonia, in the subtropical-subantarctic interaction zone (Brazil-Malvinas confluence), the thermohaline shelf-break front, and at local ocean fronts (Figs. 3C, $4 \mathrm{~A}-\mathrm{C}$ ). Patagonia has been recognized as an important area for atmospheric $\mathrm{CO}_{2}$ capture (carbon sink): most $\mathrm{CO}_{2}$ storage occurs in the midshelf region (highest surface chlorophyll-a values) whereas nearshore waters are $\mathrm{CO}_{2}$ source to the atmosphere (Bianchi et al., 2005, 2009; Kahl et al., 2017). Because this area of the thermohaline circulation regulates ocean dynamics, carbon exchange and productivity, it is commonly described as the worldwide climate pump (circulation, physical or solubility, and biological) (e.g., Gottschalk et al., 2016; Kahl et al., 2017).

\section{Materials and methodological approach}

Variations of $\delta^{18} \mathrm{O}$ and $\delta^{13} \mathrm{C}$ of "in situ" shells with unaltered microstructure are assumed to record general environmental conditions of the oceanic waters where they lived (salinity, SST, productivity/ nutrients availability). Apart from being dominant in the area, by using these single species for comparison, we attempted to preclude the possibility that $\delta^{13} \mathrm{C}$ differences were related to different feeding strategies or to species-specific vital effects (Lartaud et al., 2010); such aspects would hinder regional and across-time comparisons of palaeoenvironmental interpretations.
Among the $>200$ field samples (ca. $400 \mathrm{~cm}^{3}$, sediment and biogenic content) recovered from Late Quaternary previously dated terraces, between San Antonio Oeste and Punta Bustamante (north of Río Gallegos), well preserved shells of $P$. antiqua and T. atra were selected from three geographical sectors: (1) northern (Golfo San Matías area to Cabo Raso area); (2) central (Golfo San Jorge: Bahía Camarones to Bahía Lángara-P.Mazarredo); (3) southern (Bahía Laura-Puerto San Julián) (Fig. 1A) (A.1, A.2). South of Puerto San Julián, only coastal deposits at Río Coig and Rincón del Buque exhibit abundant molluscan shells, but the assemblages are much less diverse, show greater taphonomic loss (Cummins et al., 1986), with $P$. antiqua occurring only rarely and $T$. atra not being present. In the area around the eastern Magellan Strait these species were not found. The modern, dead collected shells came from the intertidal and upper infralittoral adjacent to the fossiliferous sites at the same coastal sectors (Fig. 2L), except for T. atra which does not live in Patagonia nowadays.

For $P$. antiqua, 45 specimens of similar size were analysed, which came from six Holocene fossiliferous localities (mostly mid-Holocene sensu Walker et al., 2019), nine Late to Middle Pleistocene (mostly MIS 5e) according to previous dating (Appendix A1, A2) and six are from modern sites (Table 1) (A.3.A, Table A.3). Shells of T. atra (33 specimens of similar size) came from six coeval Late to Middle Pleistocene sites (mostly MIS5e) and from the modern intertidal zone along northern and central Chile (Antofagasta and Pucatrihue, respectively; for comparison since they do not exist in Patagonia today) (A.3.A, Table A.4). The selected shells did not show evidence of taphonomic loss due to long-distance movement (i.e., breakage, physical abrasion, dissolution). Many $P$. antiqua specimens occurred with the hinge ligament still intact and/or with jointed valves and/or in life position (Fig. 1C-E) while most $T$. atra retain the original colour and luster of their fragile shells (Fig. 1F, G, H) and maintain the inner nacreous layer intact; none - or only minor within habitat - post-mortem transport can be assumed. To evaluate extensive diagenetically altered shell material SEM photographs, X-Ray diffraction analyses, and Edax analyses were performed in order to check the pristine (aragonitic) composition and preservation of the shell layers (A.3.B). Moreover, if diagenetic alteration had occurred, altered shell carbonate would shift isotope ratios to more negative values, especially for $\delta^{18} \mathrm{O}$ and reduced or absent

Table 1

Localities sampled for isotope analyses ordered from north to south. Geographical position and age (modern, fossil Holocene, Late to Middle Pleistocene). P: Protothaca antiqua; T: Tegula atra.

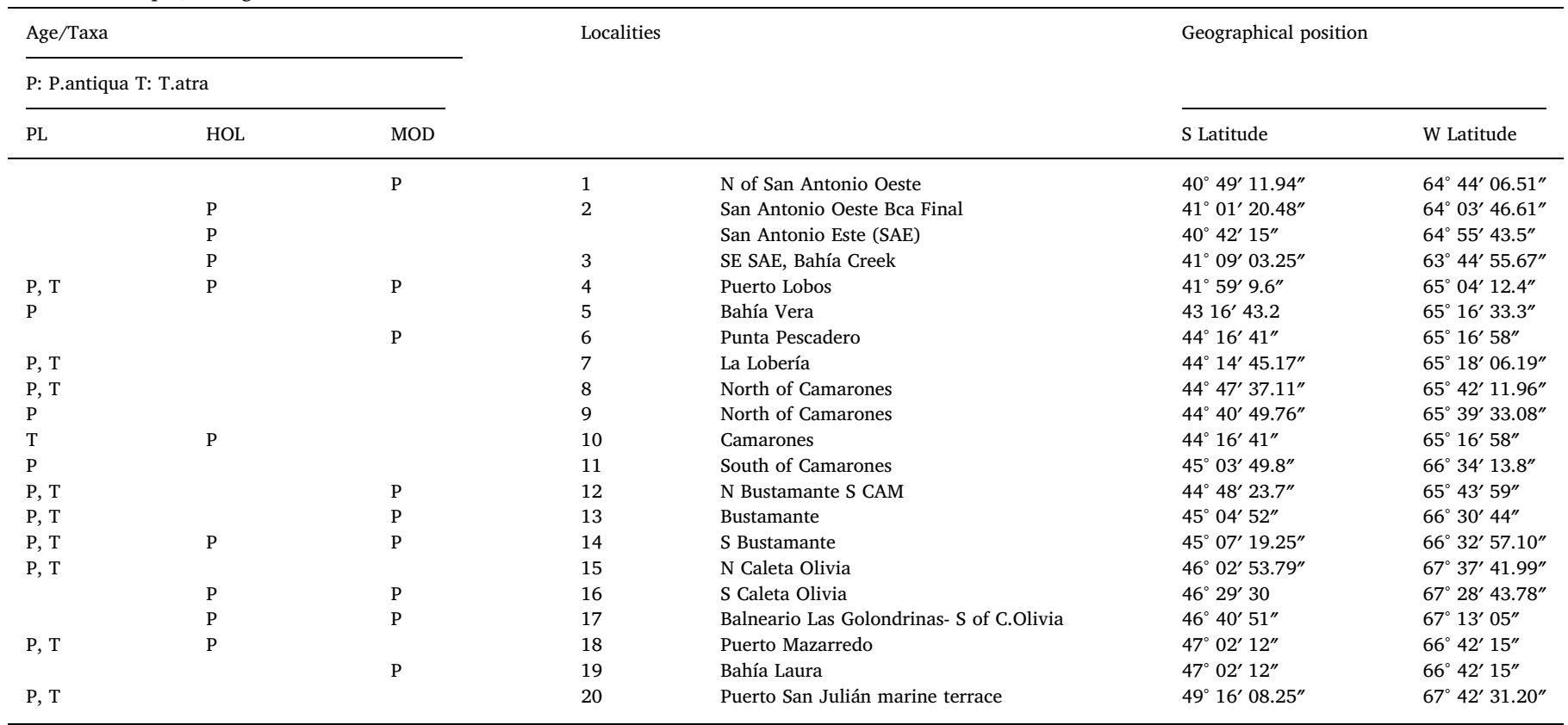


A

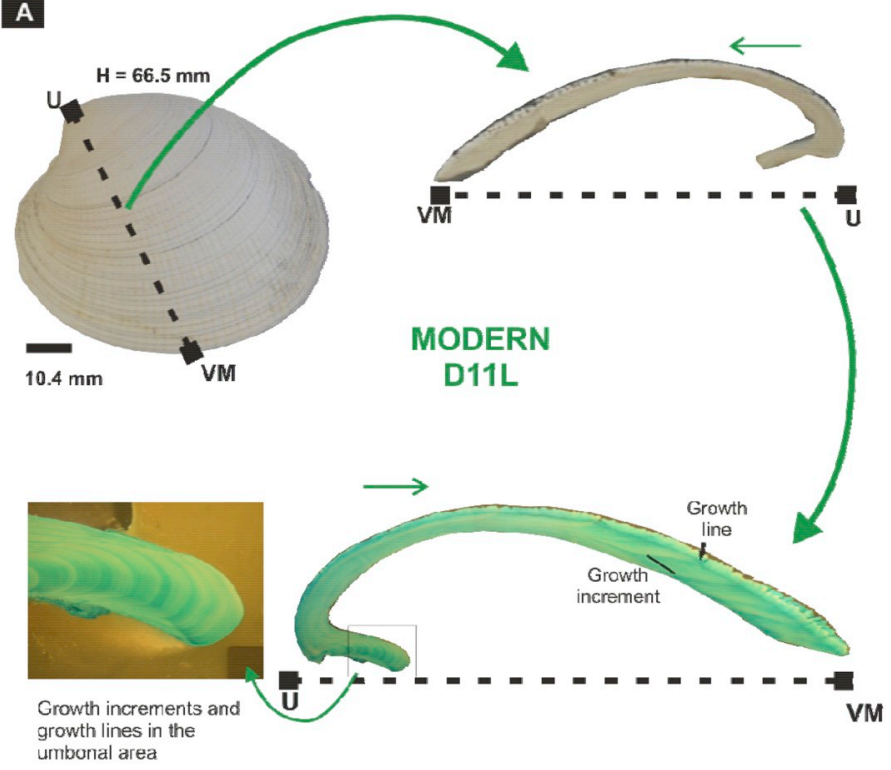

B

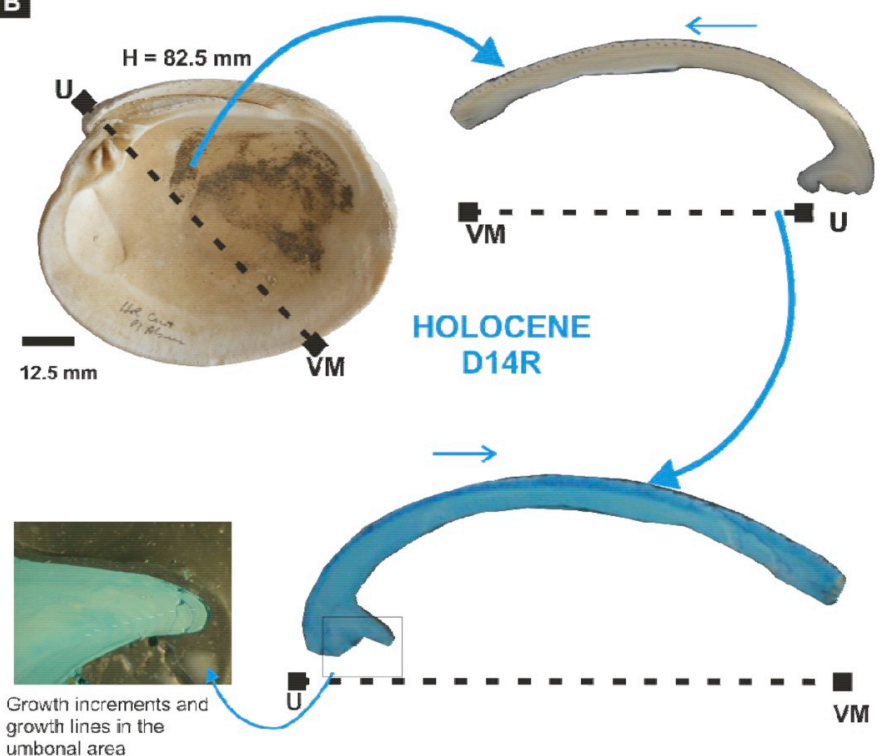

Fig. 5. Shell cross sectional cuts of $P$. antiqua for ontogenetic isotope analyses. (A): modern specimen D11L (Height $=66.5 \mathrm{~mm}$ ), north of Caleta Olivia (sample (MPA010-26). (B): mid-Holocene shell specimen D14R (Height $=82.5 \mathrm{~mm}$ ), Playa Alsina quarry, north of Caleta Olivia (sample PA010-40). Small arrows indicate direction of shell growth. The number of growth lines in the umbonal area generally coincides with the number of growth lines from the umbo (U) towards the ventral margin (VM) (shell growth direction) (in the modern specimen $11 \mathrm{~L}$, approximately 7). Note that the growth lines (darker colour) are better stained with Mutvei's solution in the modern specimen (D11L) but less well stained in the fossil specimen (D14R). More information about the technique in Schöne et al. (2005) and Schöne and Surge (2012). Analysis carried out at University of Mainz (Germany).

ontogenetic cyclicity in both $\delta^{18} \mathrm{O}$ and $\delta^{13} \mathrm{C}$ in the fossil bivalve shells would be expected (but see results in Fig. 5).

\subsection{Isotope measurements}

Firstly, a modern and a fossil Holocene $P$. antiqua shell were measured in more detail (University of Mainz): three cross sectional cuts (umbo-ventral margin) were performed (Fig. 5A, B). One shell cut was stained with Mutvei solution (Schöne et al., 2005) to better distinguish annual growth increments (light blue) from annual growth lines (dark blue). In the other shell cut, powder samples for $\delta^{18} \mathrm{O}$ and $\delta^{13} \mathrm{C}$ measurements were drilled along the major growth axis (umbo-ventral margin) from the inner outer shell layer (composed prismatic, $\mathrm{CP}$; A.3.B) of the younger stages (avoiding eventual ontogenetic effects on the $\delta^{13} \mathrm{C}$ signal, as reported at mature stages for several bivalve species; e.g., Lorrain et al., 2004; Gillikin et al., 2007) in order to assess if the fossil shells record the same modern cyclycity (annual, subannual). A detailed sclerochronological analysis (high resolution seasonal/subseasonal variations) is beyond the scope of this study and was published elsewhere (Rubo et al., 2018). Secondly, $\delta^{18} \mathrm{O}$ and $\delta^{13} \mathrm{C}$ were measured from concentric growth lines of the first full years of growth in 45 single shells; bulk values per specimen according to locality and age were afterwards used to obtain latitudinal and across time trends (Fig. 6).

At the University of Arizona, whole specimens of T. atra were measured and samples of $P$. antiqua were drilled across what appeared to be the first full year of growth based on external growth lines. Between 11 and 16 shallow samples were drilled with a $0.3 \mathrm{~mm}$ diameter drill bit. Sampling started before the first growth line in the target year, crossed the full year of growth and ended after the second growth line. In addition, powder was drilled in a continuous trench across the exterior of the shell to represent an average sample for the full life of both gastropods and bivalves yielding bulk samples which values were considered. The $\delta^{18} \mathrm{O}$ and $\delta^{13} \mathrm{C}$ of carbonates were measured using an automated carbonate preparation device (KIEL-III) coupled to a gasratio mass spectrometer (Finnigan MAT 252). Powdered samples were reacted with dehydrated phosphoric acid under vacuum at $70{ }^{\circ} \mathrm{C}$. The isotope ratio measurement is calibrated based on repeated measurements of NBS-19 and NBS-18 and precision is $\pm 0.10 \%$ for $\delta^{18} \mathrm{O}$ and $\pm 0.08 \%$ for $\delta^{13} \mathrm{C}(1 \sigma)$.

At the University of Mainz (Institute of Geosciences), carbonate samples were processed in a Thermo Finnigan MAT 253 continuousflow isotope ratio mass spectrometer coupled to a GasBench II. Carbonate powder samples were dissolved with concentrated phosphoric acid in helium-flushed borosilicate exetainers at $72{ }^{\circ} \mathrm{C}$. Data were calibrated against NBS-19. On average, internal precision $(1 \sigma)$ was better than $0.03 \%$ in case of $\delta^{13} \mathrm{C}$ and better than $0.10 \%$ in case of $\delta^{18} \mathrm{O}$. Since both laboratories calibrate against NBS-19, a lab intercomparison was not needed. Also, different kind of measurement strategies (sampling at each lab had specific research targets) does not affect any of our findings.

\section{Results}

Figs. 6-9 synthesize isotope results on $P$. antiqua and T. atra shells (full data in A.3.A, Tables A.3 and A.4): Fig. 6 shows total $\delta^{18} \mathrm{O}$ and $\delta^{13} \mathrm{C}$ measurements on $P$. antiqua between Golfo San Matías and Puerto San Julián (86 modern, 73 fossil Holocene, and 129 Late to Middle Pleistocene). For $\delta^{18} \mathrm{O}$, a large dispersion is apparent for all ages. The $\delta^{13} \mathrm{C}$ variations show similar modern and Holocene trends (decreasing southwards) but a different Late to Middle Pleistocene pattern. Highest $\delta^{18} \mathrm{O}$ and $\delta^{13} \mathrm{C}$ values for all ages were observed in the Golfo San Matías (northern sector). Overall, modern values range from $\neg 0.17$ to $+1.74 \%$ for $\delta^{18} \mathrm{O}$ and from $\neg 0.35$ to $+2.67 \%$ for $\delta^{13} \mathrm{C}$; the Holocene, from $\neg 0.28$ to $+1.79 \%$ for $\delta^{18} \mathrm{O}$ and from +0.15 to $+2.71 \%$ for $\delta^{13} \mathrm{C}$; the Late Pleistocene, from $\neg 0.26$ to $+1.87 \%$ for $\delta^{18} \mathrm{O}$ and from $\neg 0.31$ to $+2.64 \%$ for $\delta^{13} \mathrm{C}$. A classical ANOVA of $\delta^{18} \mathrm{O}$ and $\delta^{13} \mathrm{C}$ values of $P$. antiqua for Late to Middle Pleistocene vs. mid-Holocene, Late to Middle Pleistocene vs. Modern, and mid-Holocene vs. Modern sample sets showed statistically significant differences.

Fig. 7 shows $\delta^{18} \mathrm{O}$ and $\delta^{13} \mathrm{C}$ measurements for individual shells of $T$. atra from Late to Middle Pleistocene deposits between Puerto Lobos (Golfo San Matías) and Puerto San Julián and for modern shells from Chile (Antofagasta, Pucatrihue) (Table A.4, A.4). Overall, the Late to Middle Pleistocene $\delta^{13} \mathrm{C}$ trend reveal highest values at Golfo San Jorge 

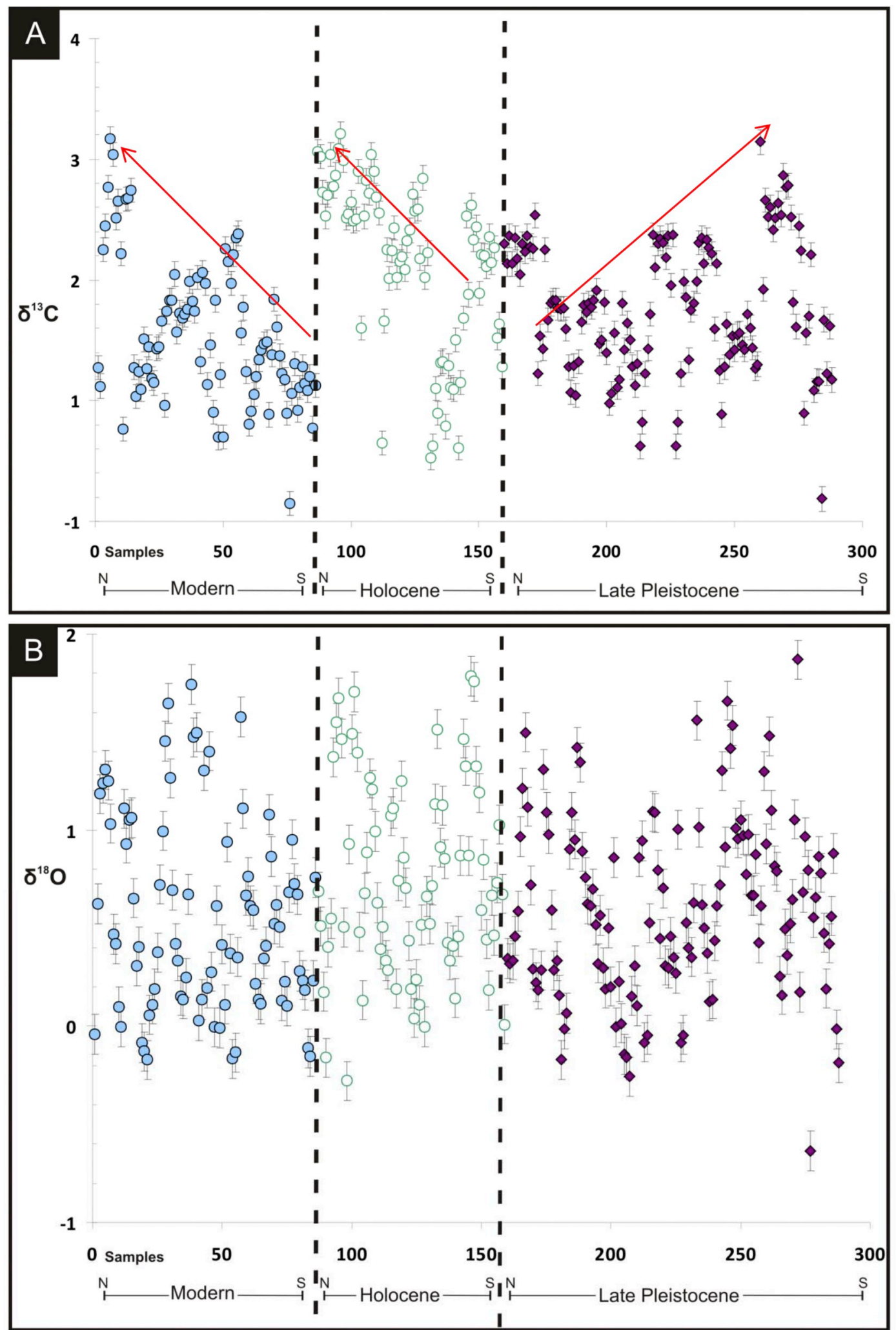

Fig. 6. Oxygen and carbon stable isotope (in \% VPDB) variation in $P$. antiqua (total values $=288$ ). Localities arranged from north $(\mathbf{N})$ to south $(\mathbf{S})$ and according to each age distribution (Modern: 86 samples; fossil Holocene: 73 samples; Late to Middle Pleistocene: 129 samples). X axis: number of samples analysed for each age distribution. Y axis: isotope values (top: $\delta^{13} \mathrm{C}$; bottom: $\delta^{18} \mathrm{O}$ ). Analysis carried out at Environmental Isotope Laboratory, Department of Geoscience, University of Arizona, USA. (Error bars \pm 1 sigma are smaller than the size of the symbol and are not represented on the plot; but see A.3.C). (A) Carbon isotope values obtained for P. antiqua (all values). (B) Oxygen isotope values obtained for $P$. antiqua (all values). A large dispersion is apparent for $\delta^{18} \mathrm{O}$. For $\delta^{13} \mathrm{C}$, the Pleistocene pattern is different to the mid-Holocene and modern (increased northwards). The excellent preservation of the mineralogy and microstructure of the shells (SEM photographs, $\mathrm{XR}$ analyses, Appendix A.3) together with low correlation between $\delta^{18} \mathrm{O}_{\text {shell }}$ and $\delta^{13} \mathrm{C}_{\text {shell }}$ (not shown) support a lack of diagenetic alteration and their reliability as palaeoenvironmental tools. Note that the error bars for text Fig. 7 (bulk values for Tegula atra) and Fig. 9 (bulk values for Protothaca antiqua) could not be represented. In all cases, the error bars are between 0.004 and 0.010 and within the illustrated symbols. 

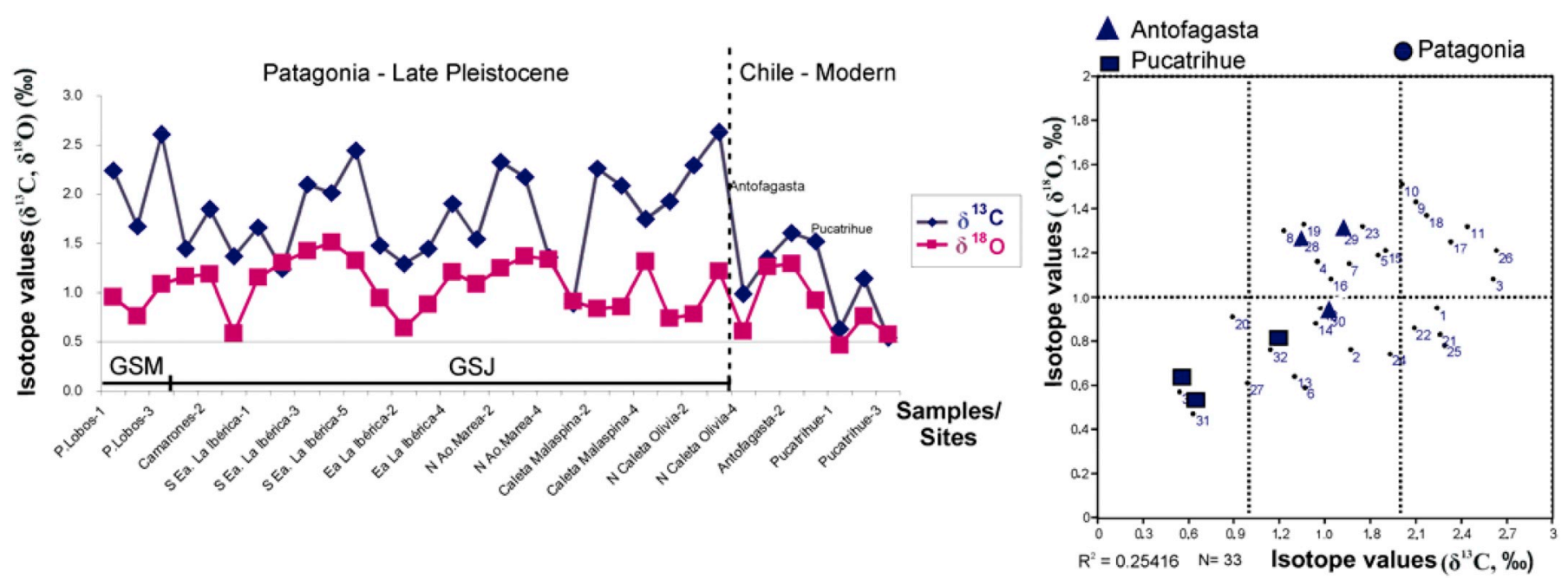

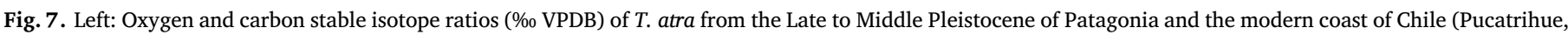

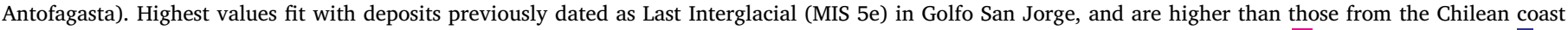

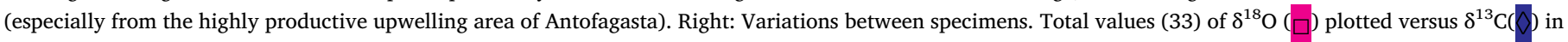

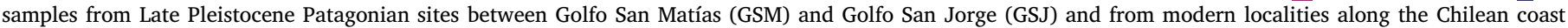

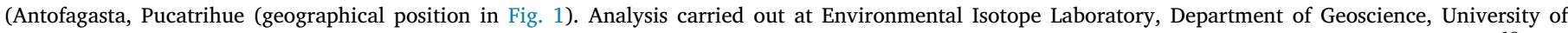

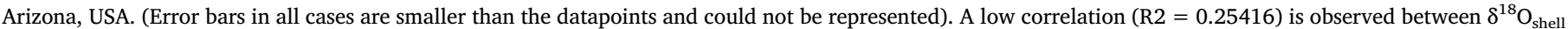

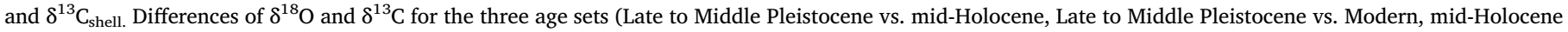
vs. Modern) yielded statistically significant differences.

(especially for deposits previously dated as MIS 5e).

Profiles of selected $P$. antiqua shells of each age distribution (Fig. 8) exhibit a typical, cyclic pattern (ontogenetic, seasonal) as commonly reported for bivalve shells (e. g., Jones, 1983; Krantz et al., 1987; Rubo et al., 2018).

Geographical and temporal patterns emerge from a plot of bulk isotope values of $P$. antiqua against latitude along Patagonia and grouped by their modern age, Holocene (mostly mid-Holocene) and Late to Middle Pleistocene interglacial shorelines (mostly MIS5e) (Fig. 9) (A.5). The modern $\delta^{18} \mathrm{O}$ and $\delta^{13} \mathrm{C}$ values are maximum at Golfo San Matías and decrease southwards. For $\delta^{18} \mathrm{O}$, the general patterns are: 1) modern and Holocene trends, with maximum peaks at San Antonio Oeste (NSAO, Golfo San Matías; Golfo San Matías Coastal Front, SMCF); 2) a Holocene trend increasing southwards, especially around south of Caleta Olivia (S COL) at Golfo San Jorge; and 3) higher Late to Middle Pleistocene values compared with the Holocene and modern south of Golfo San Matías, especially between Bustamante and Mazarredo (northern and southern Golfo San Jorge). For $\delta^{13} \mathrm{C}$ we observe 1) similar modern and Holocene trends, with maximum peaks at Golfo San Matías (SMCF); 2) higher Holocene than modern values, but lower than for the Late to Middle Pleistocene interglacial shorelines; and 3) highest Late to Middle Pleistocene levels in Camarones-Bustamante (Northern Golfo San Jorge Frontal System, NGSJFS, or northern Patagonian Frontal System) and, especially, around Puerto Mazarredo (near the Southern Golfo San Jorge Frontal System, SGSJFS, or southern Patagonian Frontal System, Figs. 3E, 4A). A multiple regression analyses of $\delta^{18} \mathrm{O}$ and $\delta^{13} \mathrm{C}$ vs. latitude (and associated environmental physical/ biotic features of the Patagonian shelf, e.g., salinity, SST, winds-currents, chlorophyll-a concentrations/ocean fronts) showed no relation with latitude for $\delta^{18} \mathrm{O}$ values for all ages. For $\delta^{13} \mathrm{C}$, an inverse relation for the modern and mid-Holocene sets are seen, but none for the Late to Middle Pleistocene, when the highest $\delta^{13} \mathrm{C}$ peaks match with the present position of coastal fronts (thermal and tidal) (Fig. 9).

\section{Discussion}

Overall, our $\delta^{18} \mathrm{O}$ and $\delta^{13} \mathrm{C}$ values for shells of both species (Figs. 6 , 7; Tables A.3, A.4) fall within or very close to the common range reported for carbonates in modern oceanic waters $\left(\delta^{13} \mathrm{C}\right.$ values around $+1.0 \%$ and $\delta^{18} \mathrm{O}$ close to zero for open marine conditions) according to the literature (e.g., Maslin and Swann, 2006; Rohling, 2013). The modern values for $P$. antiqua match with the range obtained for livecollected specimens at central Golfo San Jorge (Rubo et al., 2018). The cyclic pattern in the $\delta^{18} \mathrm{O}$ profiles (Fig. 8) (within specimen variations) is most likely due to seasonal temperature variations, while the $\delta^{13} \mathrm{C}$ values result from the interaction of metabolic effects associated with ontogeny and environmental features (Maslin and Swann, 2006; Schöne and Surge, 2012; Rubo et al., 2018) like phytoplankton availability/ productivity in Patagonian shelf waters (Carreto et al., 2007, 2016). To sum up, $\delta^{18} \mathrm{O}$ variations in the area of study are primarily a product of salinity and secondarily of SST; $\delta^{13} \mathrm{C}$ values respond to nutrient concentration/chlorophyl-a/primary productivity.

Concerning the reliability of the fossil results as palaeoenvironmental tools, the excellent preservation and the pristine shell mineralogy and microstructure of $P$. antiqua and $T$. atra, together with the low correlation between their $\delta^{18} \mathrm{O}$ and $\delta^{13} \mathrm{C}$, and similar fossil and modern cyclicity ( $P$. antiqua) (Fig. 8A-C), support the lack of diagenetic alteration, a feature that would argue for their use as a record of environmental conditions of the waters where they lived (an exception is one shell from San Julián, with low $\delta^{18} \mathrm{O}$ most likely due to groundwater discharge in an area of restricted circulation, Carol and Alvarez, 2016; note a SEM photograph showing a small area of this shell which seems to have suffered a minimum degree of dissolution, A.3.B).

Under this assumption, it is interesting to note that the trends in shell geochemistry through time (each age distribution considered) match well with the overall big picture of palaeobiodiversity, palaeobiogeographical and ichnological evidence provided by the whole molluscan assemblages. Four independent sources of evidence show the same general patterns, latitudinally and across time, which overall could be gathered as "windows" for physical and biological controlling factors: oxygen and carbon isotope variations, records and disappearance of $T$. atra from the SWA after the Last Interglacial (Aguirre et al., 2013), geographical shifts of areas of endemism (Aguirre et al., 2011) (A.7, A.8; Figs. A.2, A.3), bioerosion intensity and ichnodiversity (Richiano et al., 2015) (Fig. 10). They altogether point to differences in palaeoclimate/palaeocirculation dynamics between the Last 

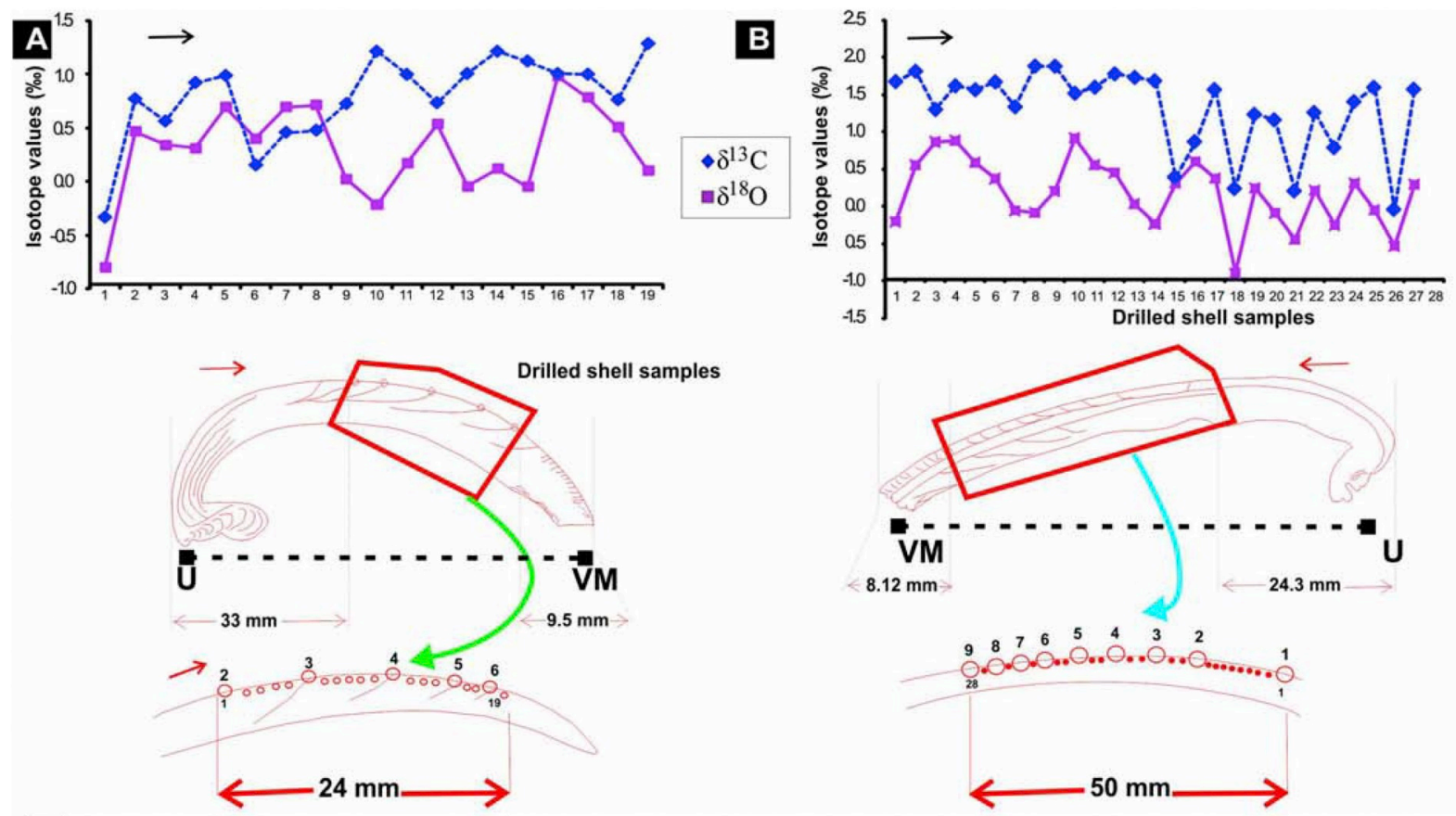

C

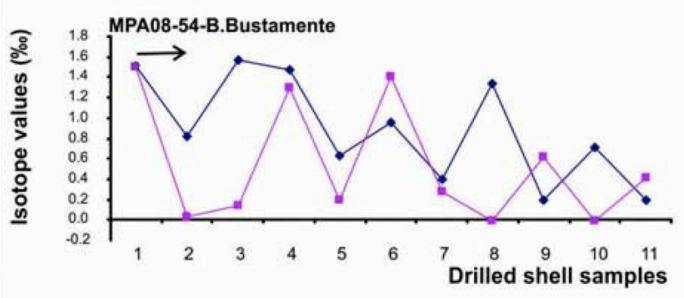

Modern

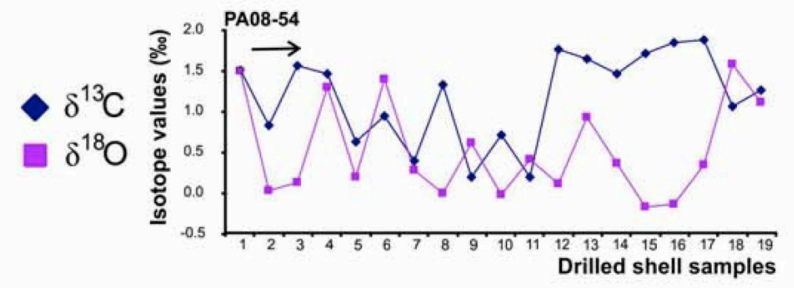

Holocene
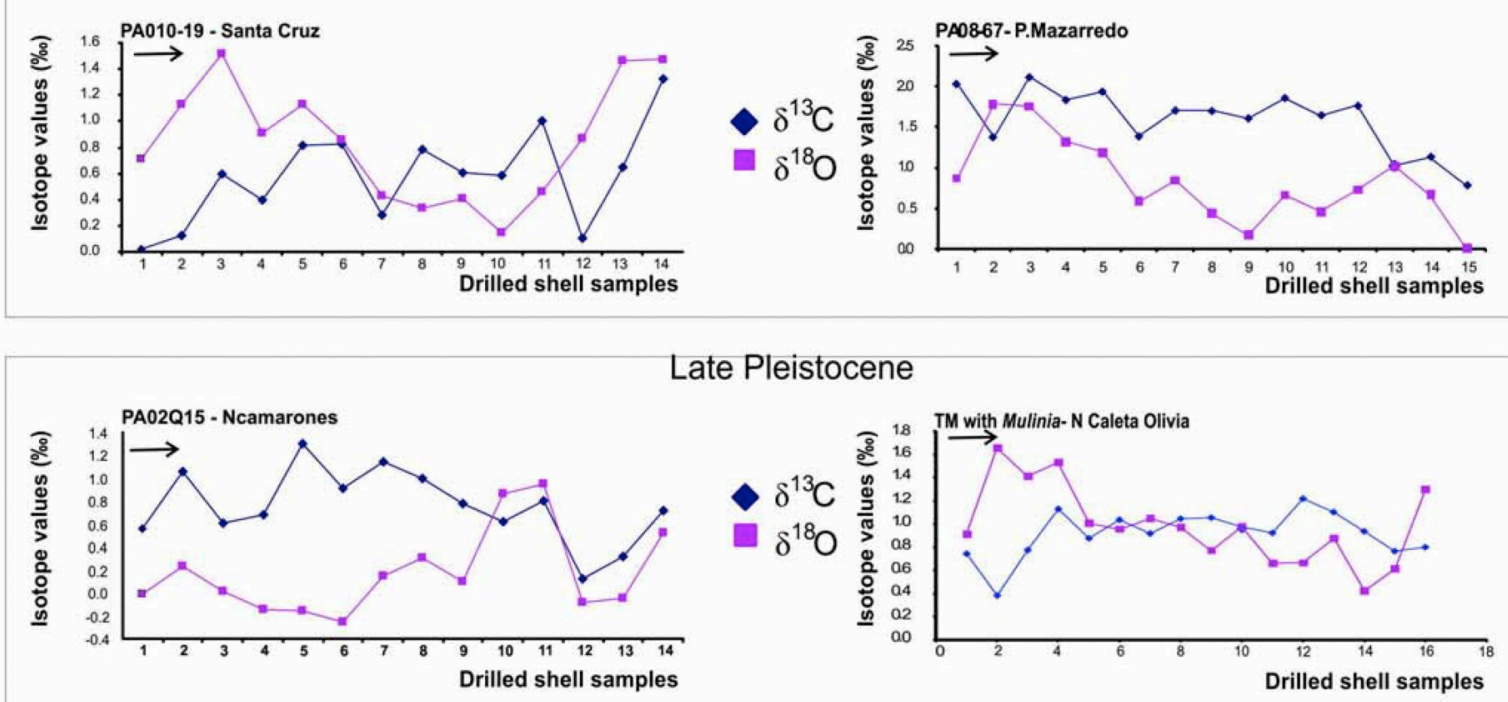

Late Pleistocene
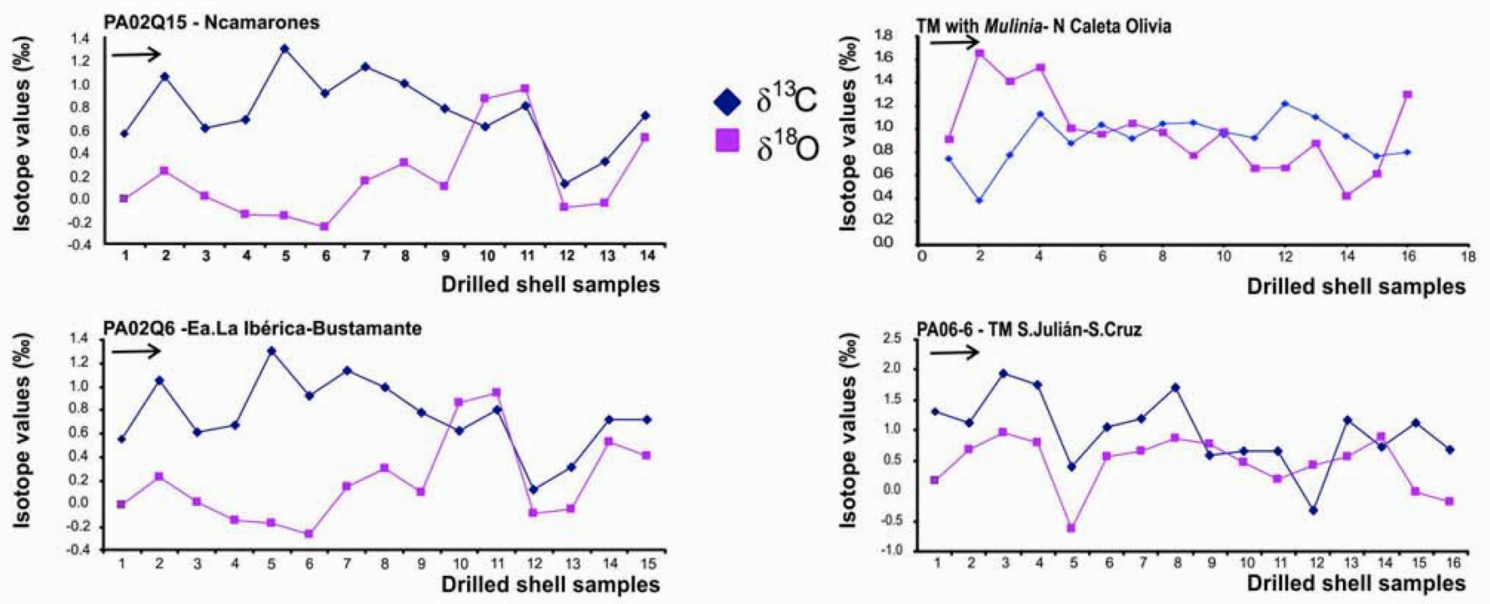


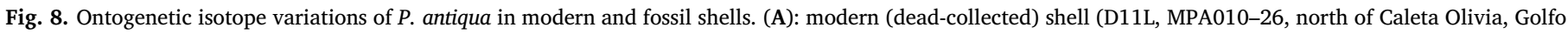

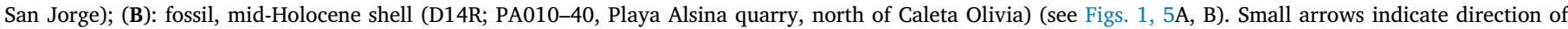

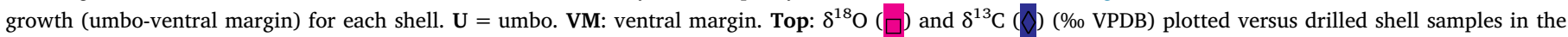

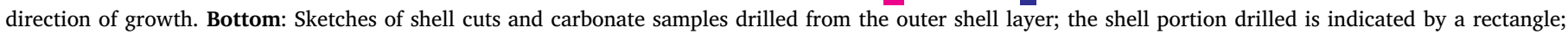

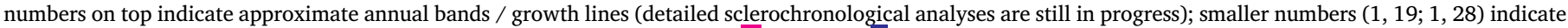

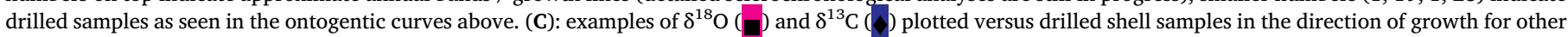

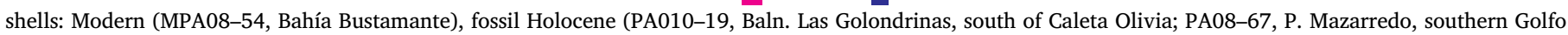

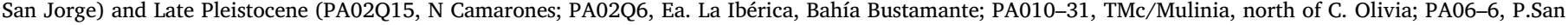

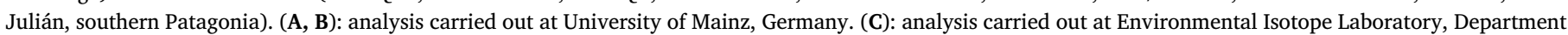
of Geoscience, University of Arizona, USA. The same cyclicity of $\delta^{18} \mathrm{O}$ and $\delta^{13} \mathrm{C}$ is observed in modern and fossil shells. Isotope reference scale is VPDB.

Interglacial vs. the mid-Holocene and present.

Our results, however, are indicative of large-scale macrogeographical palaeoclimate/palaeocirculation comparative trends and long-term records of palaeoenvironmental conditions only - in contrast to high resolution data from deep-sea sediments due to several facts, mainly the nature of nearshore molluscan assemblages which can yield unprecise age ranges due to time-averaging (ca. 100-1000 years; Flessa and Kowalewski, 1994; Govin et al., 2015) (A.1); scarce dating and methodological age limitations still exist for the Late to Middle Pleistocene Patagonian terraces; lack of sclerochronological studies for modern T. atra; insufficient palaeoceanographic/palaeoclimate models are available for the southern SWA-Southern Ocean especially for the Last Interglacial.

\subsection{What can stable isotope records tell us about environmental conditions in Patagonia?}

Between Golfo San Matías and San Julián (Fig. 1), a number of modern physical features (e.g., substrate nature, winds and currents, salinity, SST) are quite similar at the sampled areas (Figs. 3, 4) (A.6). The primary differences are in the local structure of the water massescirculation, nutrients/productivity-ocean fronts (Acha et al., 2004; Bianchi et al., 2005), and these are preserved as slight differences in shell stable isotope ratios observed between areas and also through time (Fig. 9).

\subsubsection{Oxygen-isotope variation}

The southern SWA represents an "anomalous" zone for oxygen isotopes interpretations (Rohling, 2013). This is due to the influence of
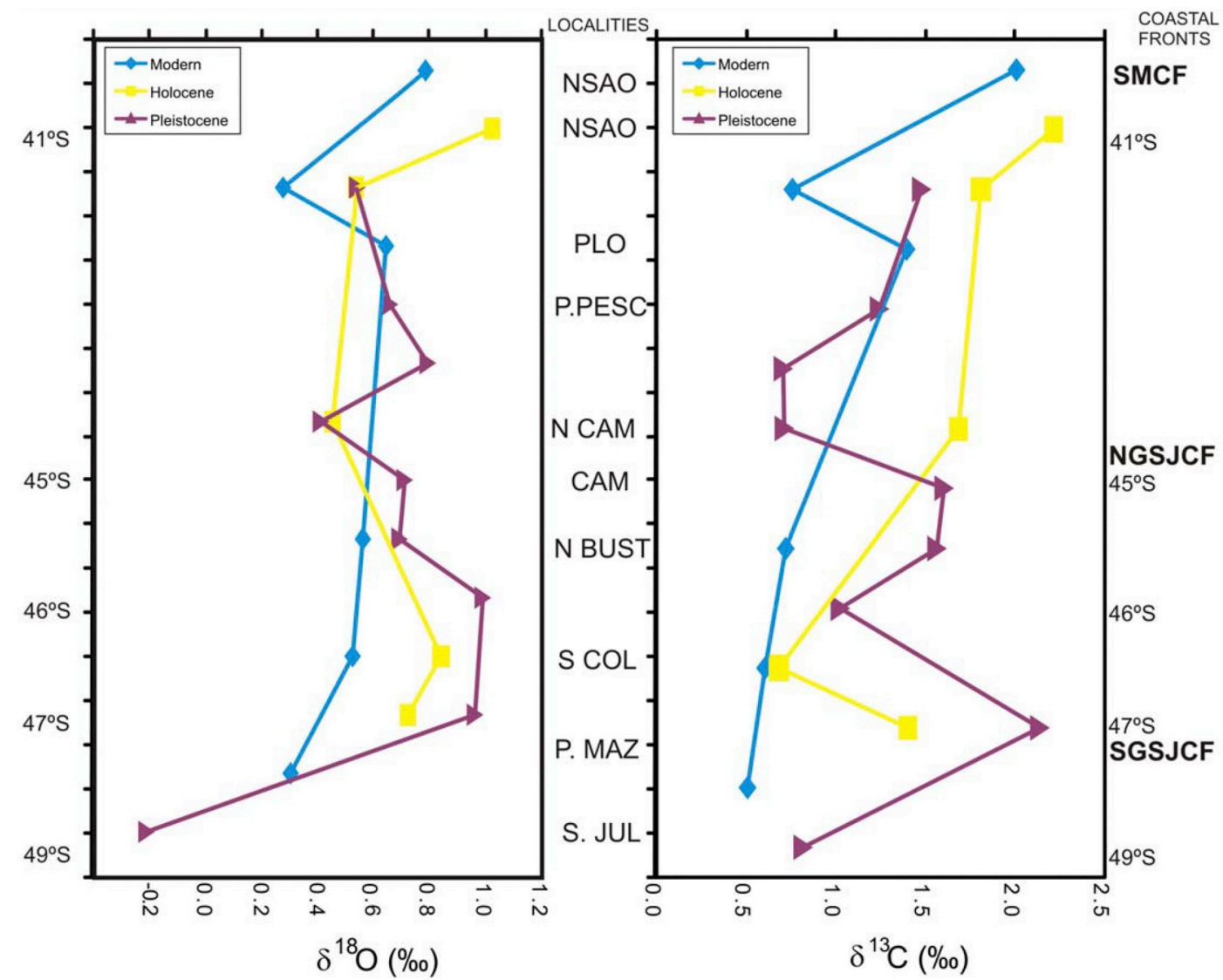

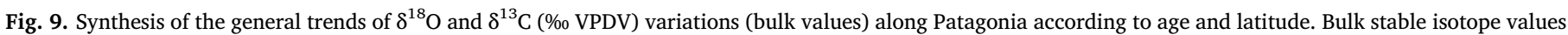

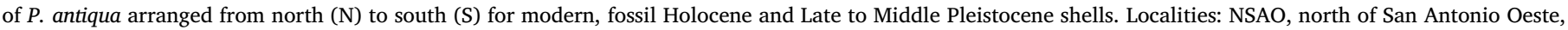

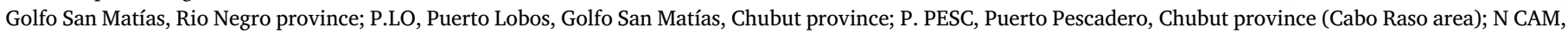

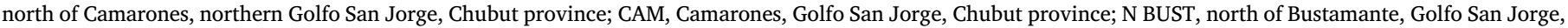

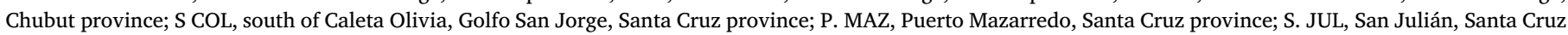

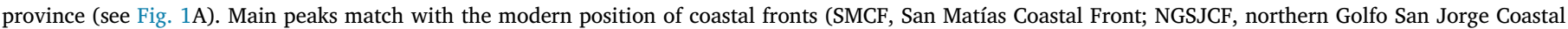

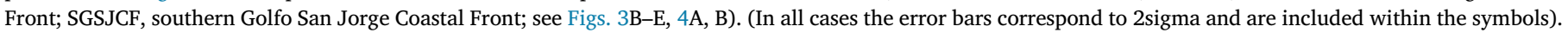




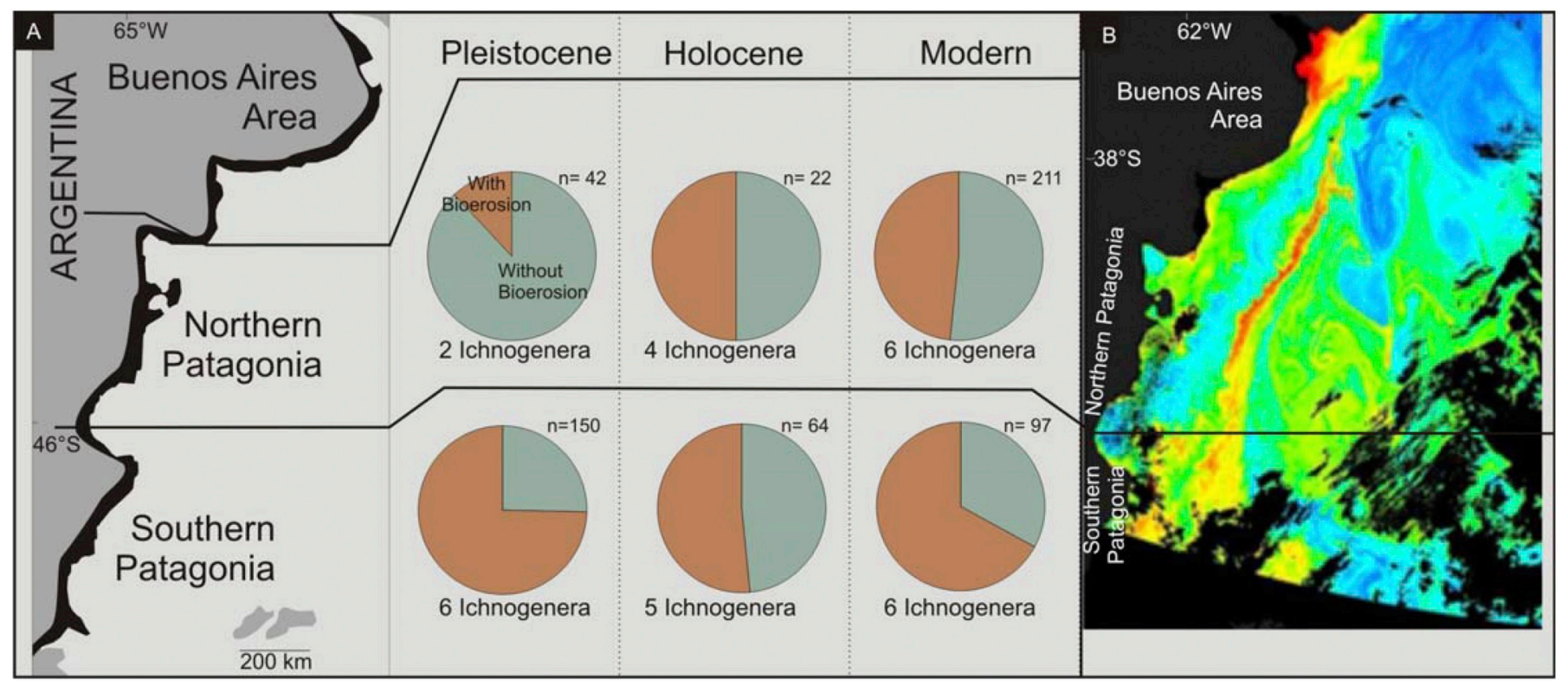

Fig. 10. Additional evidence for general broad scale trends of palaeoclimate and palaeoceanographical changes. Bioerosion patterns of molluscan shells in the southwestern Atlantic since the Late to Middle Pleistocene from our sample localities (see Fig. 1A). (A): intensity of bioerosion traces and ichnodiversity, geographically and across time (modified from Richiano et al., 2013, 2015). (B): chlorophyll-a concentrations in the Mar Argentino (modified from CONAE). Note that maximum bioerosion intensity (proxy for productivity) matches with areas of maximum chlorophyll-a concentrations (highest nutrients, primary productivity, coastal fronts) in the less saline waters of southern Patagonia (Magellan Plume) (see also Figs. 3, 4).

the Patagonian current (subantarctic Shelf Waters; Franco et al., 2018) and the "Magellan Plume" (nutrient-rich low salinity subantarctic waters from the SEP), and to the northernmost intrusion of the SAF (cold ACC waters, less rich in nutrients, flowing via the MC along the shelf edge) (Combes and Matano, 2018; Piola and Matano, 2017; Franco et al., 2018). Unusually, lower $\delta^{18} \mathrm{O}$ values in southern Patagonian shells are thus not expected to be necessarily linked to higher SST but to lower salinity. Although this region is cool, the impact of salinity is greater than that of SST, which accounts for our lowest modern $\delta^{18} \mathrm{O}$ values in the southern sector (Fig. 9). The subantarctic influence is much lower in the northern Golfo San Jorge and in Golfo San Matías regions (Fernández et al., 2007; Piola et al., 2010; Glembocki et al., 2015).

Apart from that, higher $\delta^{18} \mathrm{O}$ values can be linked to higher salinity and/or to enhanced upwelling of cold nutrient-rich waters at coastal fronts (Bianchi et al., 2005). For instance, the modern $\delta^{18} \mathrm{O}-$ and $\delta^{13} \mathrm{C}$ -maxima occur in the northern Golfo San Matías (NSAO), where the influence of warm waters together with a reverse circulation and a longer residence time for shallow waters, are responsible for enhanced evaporation and higher salinity (Piola and Rivas, 1997; Guerrero and Piola, 1997; Rivas and Pisoni, 2010; Ruiz-Etcheverry et al., 2016), leading to higher $\delta^{18} \mathrm{O}$ values (Figs. 3, 4, 9).

No freshwater currents influence the modern Patagonian littoral; in the coastal sector analysed, only a few rivers (Chubut, Deseado, San Julián) end at the Patagonian coast, and none near our sampling localities, except for the San Julián River. In the southernmost SWA region, there exists, however, an additional source of continental freshwater from icebergs calving from western Antarctic ice sheets (Wolff et al., 2006; Shepherd et al., 2018; Paparazzo and Esteves, 2018) which, when melting, can influence the waters - and isotopic signatures.

\subsubsection{Carbon-isotope variation}

The $\delta^{13} \mathrm{C}$ variations in shells can be biased by metabolic effects (e.g. Gillikin et al., 2007; McConnaughey and Gillikin, 2008; Lartaud et al., 2010; Schöne and Surge, 2012) but, if interpreted as reflecting $\delta^{13} \mathrm{C}$-DIC (dissolved inorganic carbon) of the seawater, higher $\delta^{13} \mathrm{C}$ values would indicate higher productivity (e.g. Dutton and Lohmann, 2002; Maslin and Swann, 2006).
The $\delta^{13} \mathrm{C}$ values of shells from surface Patagonian shelf waters are linked to processes of air-sea $\mathrm{CO}_{2}$ fluxes and sinks (Bauer et al., 2013) and to ocean fronts, where the main mechanisms for primary productivity occur. Nearshore waters represent a source of $\mathrm{CO}_{2}$ (carbon flux to the atmosphere) and the mid-shelf of carbon sink (intense phytoplankton photosynthetic activity leading to strong capture of atmospheric $\mathrm{CO}_{2}$ by the ocean) (O'Malley et al., 2009; Bianchi et al., 2009; Kahl et al., 2017); the transition between both corresponds to the location of tidal fronts - near their stratified side (Acha, 2015). Higher primary productivity depends on nutrients availability, through seasonal changes and high upwelling levels, which increase nitrogen and other macro-and micronutrients, enhancing phytoplankton activity. Productivity is directly affected by temperature and salinity, vertical density stratification of the water column, depth of mixing of the upper layer, light, winds and currents (Drinkwater et al., 2010), overall controlled by both climatic and oceanographic drivers which modify ecosystems in structure and function through phytoplankton (Acha, 2015; Kämpf and Chapman, 2017).

On the other hand, through geological time, oceanic $\delta^{13} \mathrm{C}$ changes have shown trends of enriched values during colder episodes, and also, increases in wind strength at the sea surface can result in increased $\delta^{13} \mathrm{C}$ (Makou et al., 2010; Friedrich et al., 2012). Our $\delta^{13} \mathrm{C}$ shell variations can thus be regarded as palaeoproductivity proxies connected to changes in coastal fronts/upwelling in Patagonia (Carreto et al., 2007; Romero et al., 2006; Olguín-Salinas et al., 2015; Paparazzo et al., 2010, 2017) and as a response to climate change in the Drake Passage area (Paparazzo et al., 2016; Paparazzo and Esteves, 2018).

\subsubsection{Linkage with carbon isotopes-productivity-upwelling-coastal fronts-} SST

In Patagonia, with a macrotidal regime, tidal mixing leads to the formation of several local coastal tidal fronts, a few tens of $\mathrm{km}$ from the shore in austral early spring to late fall. They depend on turbulence (through winds and tidal energy) and separate well-mixed coastal waters from stratified waters offshore. In addition, the Patagonian midshelf front follows the coastal PC (subantarctic shelf water) (Bianchi et al., 2005; Romero et al., 2006; Paparazzo et al., 2010, 2017; Acha, 2015; Kahl et al., 2017; Franco et al., 2018) (Figs. 3, 4). On the other 

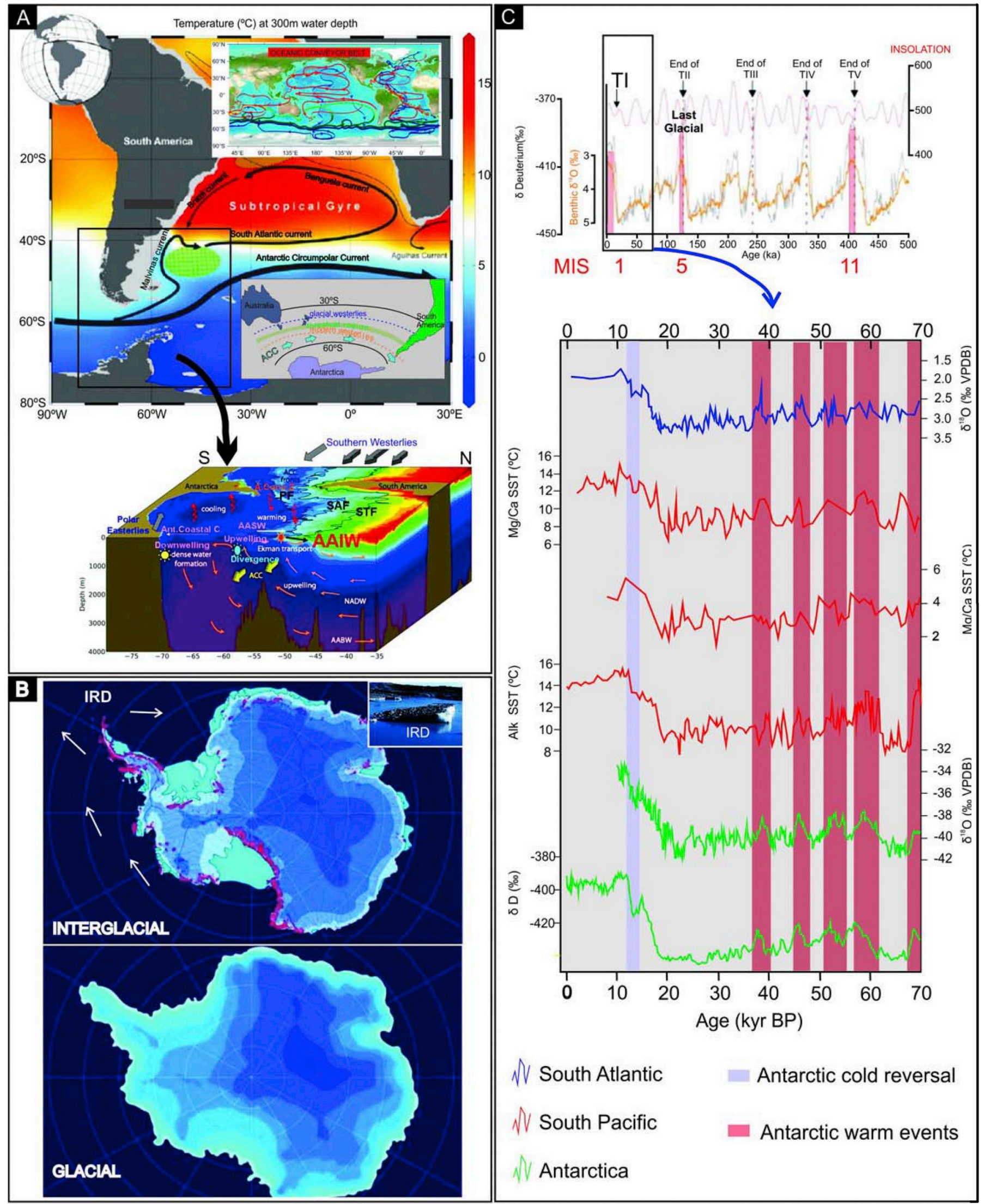


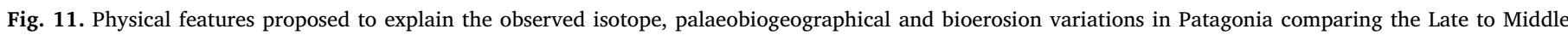

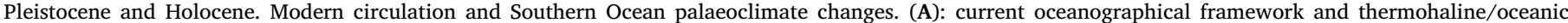

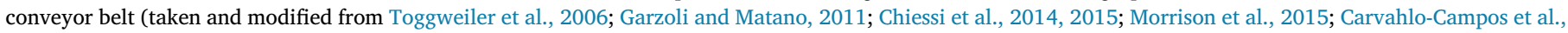

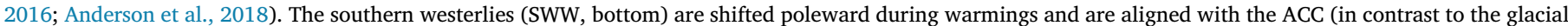

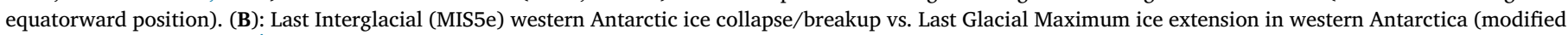

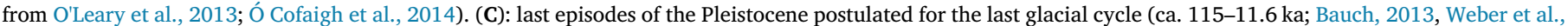

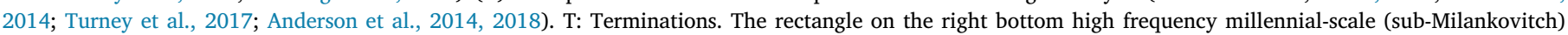

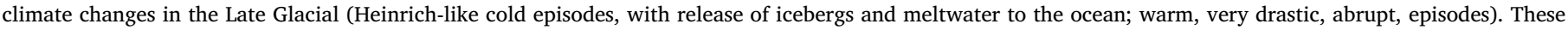

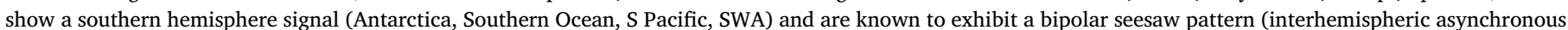

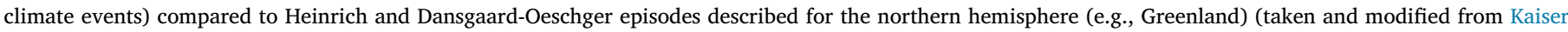

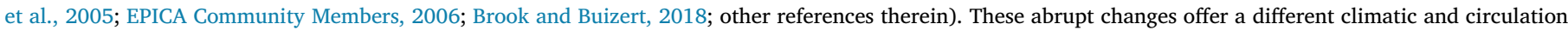

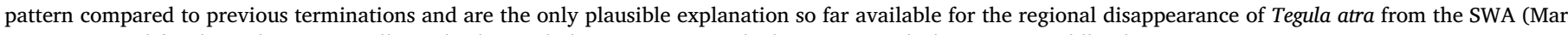
Argentino) and for the Holocene overall trends observed along Patagonia, which contrast with the Late to Middle Pleistocene.

hand, the permanent thermal front at the shelf-break is far from the coast but may have a minor influence towards the inner shelf through seasonal east-west oscillations of the MC (Franco et al., 2009), shifting towards the coast during austral autumn-winter, and affecting shallow convergence of water masses towards the coast (cold Malvinas and subantarctic shelf waters).

In relation to this point, our modern isotope trend matches with the influence of the Magellanean Plume (MP) (Fig. 3D) and with ocean fronts. The most positive $\delta^{13} \mathrm{C}$ values in the modern $P$. antiqua data set (NSAO in northern Golfo San Matías) match spatially with the San Matías Frontal System (SMFS), followed by the northern Golfo San Jorge Front (NGSJF $=$ NGSJFS), and reflect the high productivity associated with these fronts, whereby the southward decreasing trend manifests higher influence of the MP (south of Golfo San Jorgesouthern Patagonia) (Fig. 9). Minimum $\delta^{13} \mathrm{C}$ for south of Caleta Olivia (Fig. 9) is most likely associated with a different circulation regime in central Golfo San Jorge, which does not match modern coastal fronts but is characterized by lower nutrient availability (Carreto et al., 2007). In the southern Golfo San Jorge, a permanent thermohaline front occurs, which together with tidal mixing enhance productivity, while lower nutrients concentrations distinguish the central part of the gulf (Romero et al., 2006; Glembocki et al., 2015).

Regarding the mid-Holocene (in a broad sense) trend, highest $\delta^{13} \mathrm{C}$ values were recorded in NSAO (northern Golfo San Matías) like the modern trend, suggesting that the GSMFS was already active. However, higher isotope values compared to the modern imply a more intensified GSMFS during the Hypsithermal influence (ca. 7.5-4.5 ka B.P.). A plausible explanation for the frontal intensification and thus increased productivity could be the presence of warmer and more saline waters (even higher evaporation levels than today), potentially caused by a southward shift of warmer water masses, and/or an enhanced, southward displaced South Atlantic Anticyclonic center (responsible for winds from the north). A SST rise of ca. $1-2{ }^{\circ} \mathrm{C}$ during the Hypsithermal in comparison with the modern average oceanic temperatures is independently supported by the palaeobiogeographical pattern of stenothermal gastropods and bivalves northwards displaced at present ("anomalous taxa"; Aguirre, 1993, Aguirre et al., 2011, 2017) together with the absence of the cold gastropod T. atra (Aguirre et al., 2013) and is sufficient to have displaced winds, shallow water masses and the Brazil Malvinas Confluence southwards along Patagonia. In addition, the absence of T. atra (Fig. 10) and different mid-Holocene bioerosion patterns corroborate warmer SST in comparison with both the present and the Late to Middle Pleistocene (Aguirre et al., 2013; Richiano et al., 2015, 2017) (Fig. 11). In the southern Golfo San Jorge area (e.g., Puerto Mazarredo), more enriched $\delta^{18} \mathrm{O}$ and $\delta^{13} \mathrm{C}$ values can be interpreted as a result from enhanced upwelling of nutrient-rich, cool, subsurface waters at the SGSJFS front (Fig. 9). Likewise, the southwards-increasing mid-Holocene $\delta^{18} \mathrm{O}$ values are another response to upwelling, with the mid-Holocene shells of $P$. antiqua, which feeds on phytoplankton, reaching greater sizes than the modern specimens along Patagonia due to the higher food supply (A.3.D).

It is interesting to note that enhanced river drainage due to melting of the Andean glaciers could have led to higher supply of fertilizing nutrients (e.g. phosphorous, nitrogen, iron) and thus increased nearshore primary productivity. On the other hand, higher river runoff could lower salinity near the coast, which would result in more negative $\delta^{18} \mathrm{O}$ values in conjunction with high $\delta^{13} \mathrm{C}$ values in the shells. Since such a signal is not seen in our Holocene oxygen isotope values (Fig. 9), the strong upwelling (higher than at present, but lower than during the Late Pleistocene) must have quickly mixed the riverine with the marine waters.

The suggested mid-Holocene setting agrees well with climate models pointing to stronger and southward shifted wind belts during warmings in the southern hemisphere (Toggweiler et al., 2006; Toggweiler and Russell, 2008; Toggweiler, 2009; Wingenter et al., 2010), particularly during the Holocene in southernmost Patagonia (Kilian and Lamy, 2012; Fletcher and Moreno, 2012; Quade and Kaplan, 2017), associated with records of increased upwelling (Anderson et al., 2009; Anderson et al., 2018). Apart from that, a tight coupling of the Brazil Malvinas Confluence latitudinal location to the position of SSW was reported for the SWA and a more southerly position of the Brazil Malvinas Confluence after $10 \mathrm{ka}$ was documented in the Argentine margin of the SWA (Voigt et al., 2015; Howe et al., 2016). However, much work is still needed regarding a precise chronology for the Atlantic Patagonian sector. Although marine vs. continental evidence can reflect different temporal and spatial responses to climatic events, the early Holocene was warmer and a series of glacier readvances occurred during the mid-Holocene (south Patagonian icefield) between 6.1 and $4.5 \mathrm{ka}$ B.P. (colder setting) according to high resolution glacial evidence from the Lago Argentino Basin (Kaplan et al., 2016) and lake sediment records from Chile ( $51^{\circ} \mathrm{S}$, Moreno et al., 2018).

Concerning the Late to Middle Pleistocene, most outstanding are the $\delta^{13} \mathrm{C}$ maxima for both $P$. antiqua (infaunal) and T. atra (epifaunal), i.e. higher values than the modern and mid-Holocene patterns in Patagonia and modern Chile, respectively. For $P$. antiqua, comparatively low $\delta^{13} \mathrm{C}$ values in the Golfo San Matías indicate that the GSMCF salinity/thermal front was probably not yet active (less influence of warm water masses, lower SST). Along the Golfo San Jorge, highest $\delta^{13} \mathrm{C}$ values coincide with the modern position of the NGSJCF and SGSJCF tidal fronts (Fig. 9), suggesting that these fronts were already active, but more intensified (enhanced upwelling) relative to the present and to the midHolocene. Puerto Mazarredo could have been the location of the Late to Middle Pleistocene SGSJCF, with stronger upwelling than today. For the coeval Late to Middle Pleistocene T. atra, the higher $\delta^{13} \mathrm{C}$ trend in the Golfo San Jorge area (landforms mostly dated as MIS5e) compared to the modern shells from Antofagasta (highest upwelling area in the SEP today) and Pucatrihue (central Chile), reinforces the view that higher productivity levels characterized Patagonia especially during MIS5e. Overall, our patterns suggest a colder Late Pleistocene setting of enhanced productivity / upwelling, and a different circulation dynamics compared to the mid-Holocene and present (Figs. 6, 9), a southward shift of the Brazil Malvinas Confluence and a strong influence of subantarctic waters.

Furthermore, the overall Late Pleistocene differences agree well 
with independent molluscan evidence (A.7, A.8): T. atra records, molluscan palaeobiogeographical shifts, and bioerosion patterns on shells from the same assemblages. Firstly, the dominant records during MIS $5 \mathrm{e}$ of T. atra, which depends on cold waters and abundant nutrients to survive and on winds to be dispersed from the SEP into the SWA (circulation in southern Patagonia is dominated by a general northeastward flow direction; Palma et al., 2008): even slight hydrographic changes (e.g., induced by winds or nutrients cycles) would trigger changes in the stratified, vertical water column that would subsequently lead to biogeographical changes, like its disappearance from the SWA after the Last Interglacial (Aguirre et al., 2013). Secondly, the southward shift of relationships of areas of endemism through time (e.g., Late to Middle Pleistocene Parsimony Analysis of Endemicity, A.7) support a colder Late to Middle Pleistocene setting, with San Antonio Oeste (SAO) being linked to the remaining Patagonian areas of endemism during the Late to Middle Pleistocene vs. its isolation during the mid-Holocene and today (when it is a transitional area between the Bonaerensian sector and Patagonia). Thirdly, enhanced Late to Middle Pleistocene bioerosion intensity and ichnodiversity, especially along southern Patagonia, are other indicators for higher productivity levels (Figs. 10, 11). Interestingly, a net increase of primary production was documented during the Pleistocene along the SE Pacific (e.g., Filippelli and Flores, 2009), the source region for Patagonian shelf waters, and Pahnke and Zahn (2005) showed increased $\delta^{13} \mathrm{C}$ during southern hemisphere warming (northern hemisphere cooling) periods.

By contrast, so far our overall interpretations are not thoroughly in agreement with palaeoceanographic studies for the last ca. $130 \mathrm{ky}$ from northeastern and southeastern Brazil, an area of the SWA which is characterized by tropical and subtropical water masses and experienced different oceanographical dynamics, hardly influenced by the Magellan Plume and the coastal fronts of the southern SWA. For instance, foraminifera-based data indicate lower salinity and productivity during the Holocene than the Pleistocene (Nagai et al., 2010), whereas Nace et al. (2014) interpreted the lower SST and productivity of the Last Glacial Maximum as a consequence of the offshore displacement of the Brazilian current (without inferences to changes in winds or coastal fronts). On the other hand, Petró et al. (2016) found SST not significantly different between the Last Interglacial (MIS5e) and the Holocene (MIS 1) and Lessa et al. (2017) documented intense upwelling events during MIS 5e in the SWA. Furthermore, Voigt et al. (2015) inferred Holocene shifts of the southern westerlies and thus of the Brazil Malvinas confluence zone.

\subsection{Why were Patagonian waters colder and more productive during the warmer Last Interglacial?}

The question arises regarding the reason/s that could account for differential Late Pleistocene vs. mid-Holocene and present Patagonian geochemical, palaeobiological and palaeoceanographical trends. Considering that a number of processes occur between 50 and $60^{\circ} \mathrm{S}$ in the Southern Ocean (Fig. 11A) (e.g. upwelling in the Antarctic divergence zone; SAMW and AAIW formation; Antarctic ice-sheet shifts which modify salinity, SST and stratification of the water column) and that the Drake Passage controls the thermohaline circulation driven by the southern westerlies winds (SSW) (Toggweiler and Samuels, 1995), it is expected that even a minor change in any of them could trigger strong changes in circulation-upwelling-productivity in the studied region (Fig. 11A-C).

Most importantly, the poleward shift and/or strengthening of the southern westerlies winds (SWW), with maximum wind speeds currently near $50^{\circ} \mathrm{S}$ (Kilian and Lamy, 2012; Fletcher and Moreno, 2012), during warmer climate periods can lead to greater flow of cold subantarctic waters from the SEP into the Patagonian shelf (via Cabo de Hornos current, Magellan Strait and NE blowing winds along Patagonia) and to enhanced SAMW and AAIW formation (increasing upper ocean overturning); thus they are key to increase the amount of AMOC
(Wingenter et al., 2010; Flores et al., 2012; Panassa et al., 2018). Particularly, around western Antarctica, strengthened southern westerlies winds enhance upwelling processes of divergence, and during warmings ice-free areas can produce greater wind mixing and upwelling (Maksym et al., 2012). In the Drake Passage seasonal variations of nutrients are controlled by ice coverage (Paparazzo and Esteves, 2018).

In this respect, during MIS $5 \mathrm{e}$ - the only interglacial during the last 400 ka warmer than the mid-Holocene and current times (e.g., Dutton et al., 2015; Williams et al., 2015; Past Interglacials Working Group of PAGES, 2016), significant changes in palaeocirculation dynamics occurred (Bakker et al., 2015). Geological evidence suggests that oceanographic reorganizations, linked to the eccentricity maximum, led to a catastrophic termination of MIS5e that included instability of grounded and marine-based ice sheets and a West Antarctic ice sheet collapse (e.g., Hearty et al., 2007; O'Leary et al., 2013; Hansen et al., 2016) (Fig. 11B), resulting in more melting icebergs floating around the ACC and subsequently in changes in water column stratification and productivity.

Concordantly, we postulate that stronger, poleward shifted southern westerlies winds, aligned with and enhancing the ACC, led through intensified Ekman upwelling to increased formation of cold SAMW in the SEP (north of the subantarctic front) and of AAIW (north of the polar front, in the Drake Passage), overall enhancing productivity and carbon storage (Hartin et al., 2011; Hartin, 2012; Ito et al., 2015; Yao, 2017; Panassa et al., 2018; Saunders et al., 2018; de Souza et al., 2018). These are plausible mechanisms to explain colder waters and enhanced productivity along the Patagonian shelf front and more persistent tidal fronts during MIS 5e, considering that increased, colder, more productive SAMW in the SEP would have an influence on the Drake Passage area and partially reach the Patagonian shelf waters. Wind driven mixing and upwelling like in the Drake Passage control iron transportation - among other nutrients- from deep to surface waters and phytoplankton through changes in light intensity (Sachs and Anderson, 2005; Graham et al., 2015; Paparazzo et al., 2016; Paparazzo and Esteves, 2018). Moreover, Combes and Matano (2018) suggested that the seasonal variability of the Patagonian shelf circulation - south of $40^{\circ} \mathrm{S}$ - is driven by deep inflows originating in the Drake Passage.

Lastly, circulation changes in the Drake Passage, like a stronger ACC, are key to intensify the MC flux. According to Franco et al. (2009), the MC exhibits several subparallel jets with seasonal east-west displacements (the innermost cold water mass called A in Fig. 5 of Franco et al., 2009 is shifted towards the inner shelf in autumn-winter). If enhanced it is expected to increase cooling, modifying stratification of the water column, with some influence on the subantarctic shelf water (Figs. 3, 11) and the Patagonian mid-shelf front, boosting productivity.

\subsection{Which changes could explain the different Holocene pattern?}

After the Last Interglacial highstand (MIS 5e) (Fig. 11C) a number of environmental changes were reported to have occurred linked to Patagonia including the rising sea-level from the Last Glacial Maximum (MIS 2; lowest sea-level globally at $-120 \mathrm{~m}$ ca. $22 \mathrm{ka}$ or $48 \mathrm{ka}$ in southern Chile; García et al., 2018) across the glacial-interglacial transition ( $-40 \mathrm{~m}$ at ca. $11 \mathrm{ka}$ ) into the Holocene (Ponce et al., 2011; Isla and Schnack, 2016). Changes include for instance a very rapid warming in the Atlantic compared with the Pacific ocean; a decreasing $\mathrm{pH}$ trend (leading to ocean acidification); nutrients and salinity levels (a mosaic of changes within the Holocene); a decline in the intensification and extension of the MC and PC; and a drastic increase in river drainage (Otto-Bliesner et al., 2006; Compagnucci, 2011; Aguirre et al., 2013). Also ice-sheet changes were reported around the Antarctic Peninsula and palaeoceanographic changes in other areas of the SWA and the Southern Ocean (e.g., Gersonde et al., 2005; Otto-Bliesner et al., 2006; Ó Cofaigh et al., 2014; Carvahlo-Campos et al., 2016; Voigt et al., 2016; Sikes et al., 2017). However, considering that oceanic-atmospheric changes occurred during glacial-interglacial transitions throughout the 
whole Quaternary, as shown by ice-sheet cyclicity with astronomical control (e.g., Zachos et al., 2001; Bauch, 2013), why then are the isotope and palaeobiogeographical and ichnological patterns different and why did T. atra disappear from the SWA only in the Holocene (but succeeded to persist in MIS 9, 7 and 5).

One possible explanation, the only so far available, could be the impact of the sub-Milankovitch, very short, drastic episodes during the extremely unstable climate of the last glacial cycle (Fig. 11C): cold episodes with increased iceberg/meltwater discharges, some of which with extreme impact on the AMOC (i.e., the Heinrich events), in alternation with short-term warming periods. Although they are not exclusive for this period (they seem to have occurred since MIS 64; Hodell and Channell, 2016), they were particularly frequent and intensified between ca. 15 and $70 \mathrm{ka}$. These have also been recorded in and around Antarctica (different sites of the South Atlantic, South Pacific and Southern Ocean) and exhibit a southern hemisphere signal, although with a bipolar seesaw chronology regarding to the northern hemisphere (interhemispheric asynchronous climate events, like Antarctic warm maxima during Greenland stadials and Heinrich events) (Kanfoush et al., 2000; Pahnke and Zahn, 2005; EPICA Community Members, 2006; WAIS Divide Project Members, 2015; Anderson et al., 2014, 2018; Buizert and Schmittner, 2015; Brook and Buizert, 2018) (the interpolar difference comparing the records between Greenland and Antarctica is shown in Fig. 11C). Such events are known to have caused abrupt reorganization in oceanic-atmospheric interactions and ice sheet changes in the SE Pacific and off the Magellan Strait (Lamy et al., 2004; Kaiser et al., 2005; Caniupán et al., 2011; Kilian and Lamy, 2012; Gottschalk et al., 2016) and, as a result, seem to have resulted in a new palaeoceanographic circulation system, clearly different from the Pleistocene's astronomically (Milankovitch) controlled climate seesaw (dominated by 100 ka cycles during the Pleistocene since MIS 22, ca. $800 \mathrm{kyr}$ B.P.), leading to the Holocene and modern settings.

Even when the nature of these millennial-scale climate changes are still a subject of debate and we cannot expect to find their record in our coastal assemblages (sea level was lower than present during MIS 4-3), they are documented for southern South America, both in surface waters off Chile (Lamy et al., 2004; Kaiser et al., 2005) and in the Andean continental record (García et al., 2018), and northwards off Brazil (Carvahlo-Campos et al., 2016). The less stable climate during MIS 3 and MIS 2 compared to MIS5 (Brook and Buizert, 2018) and the associated oscillations in atmospheric $\mathrm{CO}_{2}$ concentrations -that remain so far unexplained or at least poorly constrained-, in the southern westerlies wind belt position, in release of icebergs, subglacial meltwater and in iron inputs from icebergs/meltwater around western AntarcticaDrake Passage must have had pronounced impacts on productivity (Ó Cofaigh et al., 2014; Armour and Bitz, 2015; Gottschalk et al., 2016) and are expected to have affected the geochemical properties of the southern SWA in a measurable way. We still need palaeoceanographical models for this key area to understand how these mechanisms operated in the past in the southern SWA, possibly influencing the Patagonian shelf waters and coastal fronts.

To sum up, all these changes are intertwined and linked to the worldwide thermohaline circulation, with direct implications for patterns in molluscan biogeography, bioerosion signals and stable carbon and oxygen isotope variations of dominant taxa (P. antiqua, T. atra), especially in a key climatic area of the southern SWA-Southern Ocean which is expected to react differently to climate change relative to other ocean basins (Graham et al., 2015). From this area, where there are still insufficient high resolution palaeoclimate data, all our results suggest that the reasons for a different Holocene pattern and for the local extinction of $T$. atra are linked to palaeoclimate and palaoceanographical changes which had not occurred with such regularity and repeated severity previously throughout the Pleistocene.

\section{Conclusions}

Highly dynamic coastal areas present interpretative difficulties for isotope geochemistry in comparison to deep ocean records as they are much more variable and can be exposed to multiple sources of freshwater among other factors. Despite these complications, our results for Patagonia, where very few rivers influence the nearshore zone, are useful for demonstrating general trends of palaeoproductivity-palaeocirculation at a macrogeographical scale and across time.

Concurrent with macroscale palaeobiogeographical and ichnological trends, the parallel patterns observed for variations of $\delta^{18} \mathrm{O}$ and $\delta^{13} \mathrm{C}$ in shells of $P$. antiqua and T. atra support large-scale palaeoenvironmental changes as an explanation for the latitudinal and chronological variation in geochemistry and fauna, and illustrate possible nearshore responses linked to salinity-SST, southern westerlies winds, upwelling-productivity-coastal fronts, water masses of the southern SWA-Southern Ocean, and changes in the extension of the West Antarctic Ice Sheet during warmer climate periods.

The mid-Holocene and Last Interglacial were warmer than today due to a southward shifted BMC, stronger and poleward shifted southern westerlies winds, enhanced ACC and subantarctic shelf water, and intensified ocean fronts/upwelling levels.

Oxygen isotope ratios cannot be strictly used as palaeotemperature indicators because the southern SWA is influenced by the Magellanean plume (low salinity subantarctic waters). Either differences due to salinity (primarily) or colder waters linked to upwelling are possible, depending on the geographical areas (latitude) involved.

Higher $\delta^{13} \mathrm{C}$ during the Holocene and Late to Middle Pleistocene suggest that productivity was higher than at present. Particularly the Late to Middle Pleistocene isotope trend points to colder, more productive waters, and higher upwelling rates than in the mid-Holocene, especially enhanced during the warmer MIS $5 \mathrm{e}$.

The trends observed are in agreement with our previous interpretations (e. g., Aguirre et al., 2011, 2013; Richiano et al., 2017). In general terms, our results agree with climatic interpretations so far proposed for the last two interglacials worldwide: MIS 5e warmer than the MIS 1 Hypsithermal and today. However, local sea surface palaeotemperature, palaeocirculation and palaeoproductivity features are a product of a particular southern SWA circulation, where the dynamics of the Magellanean plume together with the influence of intensified southwards shifted southern westerlies winds on the ACC and in the formation of SAMW are important control factors for geochemical properties of the oceanic waters and shell carbonate.

Repeated, abrupt climate oscillations during the last glacial cycle with significant impact on SST, ice melting and surface-ocean stratification in the western Antarctica-Weddell Sea-ACC realm are so far the only available plausible explanations to account for the different midHolocene and modern patterns, and for the regional disappearance of $T$. atra after MIS 5e.

Our interpretations would be enriched by additional high resolution sclerochronological analyses on bivalves from the same coastal deposits, and of modern T. atra from Chile, a worthwhile target for future studies of climate evolution/circulation in the SWA during the Late Quaternary leading to modern scenarios which may produce complementary useful results.

\section{Acknowledgments}

Special thanks are due to Mike Kaplan and Carlos Silva for their valuable and helpful suggestions. Also to F. Marret-Davies for her editorial work. To A. Piola, M. Acha and F. Paparazzo for useful discussions on features of the Mar Argentino and for putting their knowledge at our disposal. To L. Zapata and M. S. Raigemborn, S. Vizcaino and S. Bargo for their help with bibliographic sources. We thank J. O. Codignotto, R. Kokot, J. Hlebzsebitch, P. I. Castellanos, K. Davies, M. Soriano, A. Cortina, J. Heupel, E. Mussachio (+) for their help in the 
field trips and with logistics. To E. Ducos and L. Mormeneo for their help concerning cleaning and selection of shell materials. To A. Kang and S. Noval for assistance with the SEM photographs. To P. Hearty, T. Algeo, I. Winograd, G. de Lange and E. Gómez for useful comments and bibliography. This work was benefitted by grants from Agencia Nacional de Promoción Científica y Tecnológica (PICT 2006-468, PICT 2013-1298), CONICET (PIP 0080, 0372 and 0729), Universidad Nacional de La Plata (PI N11/587 and N11/726), Universidad Nacional del Sur (PGI 24/H123), and DAAD-Conicet and DFG -Conicet bilateral cooperation projects. A. Voelker acknowledges support from FCT through her Investigador FCT grant (IF/01500/2014) and CCMAR (UID/ Multi/04326/2019).

\section{Appendix A. Supplementary data}

Supplementary data to this article can be found online at https:// doi.org/10.1016/j.gloplacha.2019.102990.

\section{References}

Acha, E., 2015. Frontal types. In: Acha, E.M., Piola, A., Iribarne, O., Mianzan, H. (Eds.), Ecological Processes at Marine Fronts: Oases in the Ocean. Springer Briefs in Environmental Science. https://doi.org/10.1007/978-3-319-15479-4 2.

Acha, E., Mianzan, H., Guerrero, R., Favero, M., Bava, J., 2004. Marine fronts at the continental shelves of austral South America. J. Mar. Syst. 44 (1-2), 83-105.

Aguirre, M., Donato, M., Richiano, S., Farinati, E.A., 2011. Pleistocene and Holocene interglacial molluscan assemblages from Patagonian and Bonaerensian littoral (Argentina, SW Atlantic): palaeobiodiversity and palaeobiogeography. Palaeogeogr Palaeoclimatol. Palaeoecol. 308, 277-292.

Aguirre, M., Hlebzsebitch, J., Dellatorre, F., 2008. Late cenozoic invertebrate paleontology, with emphasis on Mollusks. In: Rabassa, J. (Ed.), Late Cenozoic of Patagonia and Tierra del Fuego. Developments in Quaternary Science 11. Elsevier, pp. 285-326 Chapter 14.

Aguirre, M., Richiano, S., Farinati, E., Castellanos, P., Davies, K., 2017. Diversity and distribution of micromolluscs (Gastropoda and Bivalvia) from the marine Quaternary of Argentina (SW Atlantic): palaeoenvironmental, palaeoclimate, palaeoceanographical implications. Palaeontographica, Abt. A: palaeozoology - stratigraphy 309 (1-6), 091-171.

Aguirre, M.L., 1993. Palaeobiogeography of the Holocene molluscan fauna from Northeastern Buenos Aires Province, Argentina: its relation to coastal evolution and sea level changes. Palaeogeogr. Palaeoclimatol. Palaeoecol. 102, 1-26.

Aguirre, M.L., Richiano, S., Donato, M., Farinati, E.A., 2013. Tegula atra (Lesson, 1830) (Mollusca, Gastropoda) in the marine Quaternary of Patagonia (Argentina, SW Atlantic): biostratigraphical tool and paleoclimate-palaeoceanographical signal. Quat. Int. 305, 163-187.

Anderson, H.J., Moy, C.M., Vandergoes, M.J., Nichols, J.E., Riesselman, C.R., Van Hale, R., 2018. Southern Hemisphere westerly wind influence on southern New Zealand hydrology during the Lateglacial and Holocene. J. Quat. Sci. https://doi.org/10. 1002/jqs.3045.

Anderson, R.F., Ali, S., Bradtmiller, L.I., Nielsen, S.H.H., Fleisher, M.Q., Anderson, B.E., Burckle, L.H., 2009. Wind-driven upwelling in the Southern Ocean and the deglacial rise in atmospheric CO2. Science 323, 1443-1448. www.sciencemag.org.

Anderson, R.F., Barker, S., Fleisher, M., Gersonde, R., Goldstein, S.L., Kuhn, G., Mortyn, P.G., Pahnke, K., Sachs, J.P., 2014. Biological response to millennial variability of dust and nutrient supply in the Subantarctic South Atlantic Ocean. Phil. Trans. R. Soc. A 372https://doi.org/10.1098/rsta.2013.0054. 20130054.

Armour, K.C., Bitz, M., 2015. Observed and projected trends in Antarctic sea ice. US CLIVAR Variations 13 (4), 13-19.

Bakker, P., Govin, A., Thornalley, D., Roche, D., Renssen, H., 2015. Modeling deep ocean flow speeds and $813 \mathrm{C}$ during the Last Interglacial: towards a more direct model-data comparison. Science Highlights: Glacial terminations and interglacials. Pages Magazine 23 (1), 18-19.

Baldoni, A., Molinari, G.N., Reta, R., Guerrero, R.A., 2015. Atlas de temperature y salinidad de la plataforma continental del Atlántico sudoccidental: períodos cálido y frío. Publicación Especial Contribución Inidep 1907, pp. 85.

Bauch, H., 2013. Interglacial climates and the Atlantic meridional overturning circulation: is there an Arctic controversy? Quat. Sci. Rev. 63, 1-22.

Bauer, J.E., Cai, W.-J., Raymond, P.A., Bianchi, T.S., Hopkinson, Ch.S., Regnier, P.A.G., 2013. The changing carbon cycle of the coastal ocean. Nature 504, 61-70. https:// doi.org/10.1038/nature12857.

Bernhardt, J.R., Leslie, H.M., 2013. Resilience to climate change in coastal marine ecosystems. Annu. Rev. Mar. Sci. 5, 371-392. https://doi.org/10.1146/annurev-marine121211-172411.

Bianchi, A.A., Bianucci, L., Piola, A.R., Pino, D.R., Schloss, I., Poisson, A., Balestrini, C.F., 2005. Vertical stratification and air-sea CO2 fluxes in the Patagonian shelf. J. Geophys. Res. 110, C07003. https://doi.org/10.1029/2004JC002488.

Bianchi, A.A., Pino, D.R., Isbert Perlender, H.G., Osiroff, A.P., Segura, V., Lutz, V., Clara, M.L., Balestrini, C.F., Piola, A.R., 2009. Annual balance and seasonal variability of sea-air $\mathrm{CO} 2$ fluxes in the Patagonia Sea: their relationship with fronts and chlorophyll distribution. J. Geophys. Res. 114 (C03018), 2009. https://doi.org/10.1029/
2008JC004854.

Bianchi, C., Gersonde, R., 2002. The Southern Ocean surface between Marine Isotope Stages 6 and 5d: shape and timing of climate changes. Palaeogeogr. Palaeoclimatol. Palaeoecol. 187, 151-177.

Bogazzi, E., Baldoni, A., Rivas, A., Martos, P., Reta, R., Orensanz, J., Lasta, M., Dell'arciprete, P., Werner, F., 2005. Spatial correspondence between areas of concentration of Patagonian scallop (Zygochlamys patagonica) and frontal systems in the southwestern Atlantic Fish. Oceanographica 14, 359-376.

Boyle, E., 2000. Is ocean thermohaline circulation linked to abrupt stadial/interstadial transitions? Quat. Sci. Rev. 19, 255-272.

Brook, E.J., Buizert, C., 2018. Antarctic and global climate history viewed from ice cores. Nature 558, 200-208. https://doi.org/10.1038/s41586-018-0172-5.

Buizert, Ch., Schmittner, A., 2015. Southern ocean control of glacial AMOC stability and Dansgaard-Oeschger interstadial duration. Paleoceanography 30. https://doi.org/10. 1002/2015PA002795.

Burckle, L., 1993. Late Quaternary interglacial stages warmer than present. Quaternary Science Reviews 12, 825-831.

Caniupán, M., Lamy, F., Lange, C.B., Kaiser, J., Arz, H., Kilian, R., Baeza Urrea, O., Aracena, C., Hebbeln, D., Kissel, C., Laj, C., Mollenhauer, G., Tiedemann, R., 2011. Millennail-scale sea surface temperature and Patagonian Ice Sheet changes off southernmost Chile $\left(55^{\circ} \mathrm{S}\right)$ over the past $\sim 60 \mathrm{kyr}$. Paleoceanography 26, PA3221. https://doi.org/10.1029/2010PA002049.

Carol, E., Alvarez, M.P., 2016. Processes regulating groundwater chloride content in marshes under different environmental conditions: a comparative case study in Península Valdés and SamborombónBay, Argentina. Cont. Shelf Res. 115, 33-43. https://doi.org/10.1016/j.csr.2015.12.017.

Carreto, J.I., Carignan, M.O., Montoya, N.G., Cucchi Colleoni, D.A., 2007. Ecología del fitoplancton en los sistemas frontales del mar argentino. In: Carreto, J.I., Bremec, C. (Eds.), El Mar Argentino y sus recursos pesqueros. El ambiente Marino Tomo V. INIDEP, Mar del Plata.

Carreto, J.I., Montoya, N.G., Carignan, M.O., Akselman, R., Acha, E.M., Derisio, C., 2016. Environmental and biological factors controlling the spring phytoplankton bloom at the Patagonian shelf-break front - degraded fucoxanthin pigments and the importance of microzooplankton grazing. Prog. Oceanogr. 146, 1-21.

Carvahlo-Campos, M., Chiessi, C.M., Voigt, I., Piola, A.R., Kuhnert, H., Mulitza, S., 2016. Glacial 13C decreases in the western South Atlantic forced by millennial changes in Southern Ocean ventilation. Climate of the Past Discussion. https://doi.org/10.5194/ cp-2016-59.

Chiessi, C.M., Mulitza, S., Groeneveld, J., Silva, J.B., Campos, M.C., Gurgel, H.C., 2014. Variability of the Brazil Current during the late Holocene. Palaeogeogr. Palaeoclimatol. Palaeoecol. 415, 28-36.

Chiessi, C.M., Mulitza, S., Mollenhauer, G., Silva, J.B., Groeneveld, J., Prange, M., 2015. Thermal evolution of the western South Atlantic and the adjacent continent during Termination 1. Clim. Past 11, 915-929. https://doi.org/10.5194/cp-11-915-2015.

Clark, N.A., 2014. A Molluscan Record Of Late Cenozoic Climate And Palaeoseasonality From Antarctica And South America. PhD Thesis. University of Leicester, UK. https://lra.le.ac.uk/bitstream/2381/29324/1/2014clarkncphd.pdf.

Cofaigh, C.Ó., Davies, B., Livingstone, F., Smith, J., Johnson, J., Hocking, E., Hodgson, D., Anderson, J., Bentley, M., Canals, M., Domack, E., Dowdeswell, J., Evans, J., Glasser, N., Hillenbrand, C., Larter, R., Roberts, S., Simms, A., 2014. Reconstruction of icesheet changes in the Antarctic Peninsula since the Last Glacial Maximum. Quat. Sci. Rev. 100, 87-110.

Combes, V., Matano, R.P., 2018. The Patagonian shelf circulation: drivers and variability. Prog. Oceanogr. 167, 24-43.

Compagnucci, R., 2011. Atmospheric circulation over Patagonia from the Jurassic to present: a review through proxy data and climatic modelling scenarios. Biol. J. Linn. Soc. 103, 229-249.

Cortese, G., Abelmann, A., Gersonde, R., 2007. The last five glacial-interglacial transitions: a high-resolution 450,000-year record from the subantarctic Atlantic. Paleoceanography 22, PA4203. https://doi.org/10.1029/2007PA001457.

Cummins, H., Powell, N., Stanton Jr., R.J., Staff, G., 1986. The rate of taphonomic loss in modern benthic habitats: how much of the potentially preservable community is preserved? Palaeogeogr. Palaeoclimatol. Palaeoecol. 52 (3-4), 291-320.

Dai, M., Yin, Z., Meng, F., Liu, Q., Cai, W.-J., 2012. Spatial distribution of riverine DOC inputs to the ocean: an updated global synthesis. Curr. Opin. Environ. Sustain. 4, 170-178. https://doi.org/10.1016/j.cosust.2012.03.003.

Death, R., Wadham, J.L., Monteiro, F., Le Brocq, A.M., Tranter, M., Ridgwell, A., Dutkiewicz, S., Raiswell, R., 2014. Antarctic ice sheet fertilises the Southern Ocean. Biogeosciences 11, 2635-2644. www.biogeosciences.net/11/2635/2014/doi:10. 5194/bg-11-2635-2014.

Drinkwater, K., Beaugrand, G., Kaeriyama, M., Kim, S., Ottersen, G., Perry, R., Pörtner, H., Polovina, J., Takasuka, A., 2010. On the processes linking climate to ecosystem changes. J. Mar. Syst. 79, 374-388.

Düsterhus, A., Rovere, A., Carlson, A.E., Horton, B.P., Klemann, V., Tarasov, L., Barlow, N.L., Bradwell, T., Clark, J., Dutton, A., Gehrels, W.R., Hibbert, F.D., Hijma, M.P. Khan, N., Kopp, R.E., Sivan, D., Törnqvist, T.E., 2016. Palaeo-sea-level and palaeoice-sheet databases: problems, strategies, and perspectives. Clim. Past 12, 911-921. www.clim-past.net/12/911/2016/doi:10.5194/cp-12-911-2016.

Dutton, A., Carlson, A.E., Long, A.J., Milne, G.A., Clark, P.U., DeConto, R., Horton, B.P., Rahmstorf, S., Raymo, M.E., 2015. Sea-level rise due to polar ice-sheet mass loss during past warm periods. Science 349 (6244), 153-162. https://doi.org/10.1126/ science.aaa4019.

Dutton, A., Lohmann, K., 2002. Stable isotope and minor element proxies for Eocene climate of Seymour Island, Antarctica. Paleoceanography 17 (2), 1016. https://doi. org/10.1029/2000PA000593.

EPICA Community Members, 2006. One-to-one coupling of glacial climate variability in 
Greenland and Antarctica. Nature Letters 444, 195-198. (Suppl. Mat.). https://doi. org/10.1038/nature05301.

Escati-Peñaloza, G., 2005. Variación Espacial En El Crecimiento Individual De La Almeja Rayada, Ameghinomya antiqua, En El Golfo San José. Unpublished Graduate Thesis. Universidad Nacional de la Patagonia "San Juan Bosco", Puerto Madryn (68pps).

Fernández, M., Colleoni, D., Roux, A., Marcos, A., Fernández, E., 2007. Caracterización físico-uímica del sistema bentónico en el sector sur del Golfo San Jorge, Argentina. Revista de Biologia Marina y Oceanografía 42 (2), 177-192.

Feruglio, E., 1950. Descripción Geológica de la Patagonia. Dirección General de Y.P.F., Tomo 3, Buenos Aires.

Filippelli, G., Flores, J., 2009. From the warm Pliocene to the cold Pleistocene: a tale of two oceans. Geology 37, 959-960.

Flessa, K.W., Kowalewski, M., 1994. Shell survival and time-averaging in nearshore and shelf environments: estimates from the radiocarbon literature. Lethaia 27, 153-165.

Fletcher, M.-S., Moreno, P.I., 2012. Have the Southern Westerlies changed in a zonally symmetric manner over the last 14,000 years? A hemisphere-wide take on a controversial problem. Quat. Int. 253, 32-46.

Flores, J.A., Filippelli, G.M., Sierro, F., Latimer, J., 2012. The "White Ocean" hypothesis: a late Pleistocene Southern Ocean governed by coccolithophores and driven by phosporous. Front. Microbiol. 3, 233. https://doi.org/10.3389/fmicb.2012.00233.

Franco, B.C., Palma, E.D., Combes, V., Acha, E.M., Saraceno, M., 2018. Modelling the offshore export of subantarctic shelf waters from the Patagonian Shelf. Journal of Geophysical Research: Oceans 123, 4491-4502. https://doi.org/10.1029/ 2018JC013824.

Franco, B.C., Piola, A.R., Rivas, A.L., Baldoni, A., Pisoni, J.P., 2008. Multiple thermal fronts near the Patagonian shelf break. Geophys. Res. Lett. 35, L02607. https://doi. org /10.1029/2007GL032066.

Franco, B.C., Piola, A.R., Rivas, A.L., Palma, E.D., 2009. La corriente de Malvinas: Ramas y frentes oceánicos en el mar patagónico. Ciencia Hoy 19 (114), 17-31. https://www. researchgate.net/publication/233883142.

Friedrich, O., Schiebel, R., Wilson, P.-A., Weldeab, S., Beer, C.J., Cooper, M.J., Fiebig, J., 2012. Infuence of test size, water depth, and ecology on $\mathrm{Mg} / \mathrm{Ca}, \mathrm{Sr} / \mathrm{Ca}, \delta^{18} \mathrm{O}$ and $\delta^{13} \mathrm{C}$ in nine modern species of planktic foraminifers. Earth Planet. Sci. Lett. 319-320, 133-145.

García, J.-L., Hein, A.S., Binnie, S.A., Gomez, G.A., Gonzalez, M.A., Dunai, T.J., 2018. The MIS 3 maximum of the Torres del Paine and Última Esperanza ice lobes in Patagonia and the pacing of southern mountain glaciation. Quat. Sci. Rev. 185, 9-26.

Garreaud, R., Lopez, P., Minvielle, M., Rojas, M., 2013. Large-scale control on the patagonian climate. Journal of Climate 26, 215-230. The American Meteorological Society. https://doi.org/10.1175/JCLI-D-12-00001.1.

Garzoli, S.L., Matano, R., 2011. The SouthAtlantic and theAtlantic meridional overturning circulation. Deep-Sea Research II 58, 1837-1847.

Gersonde, R., Crosta, X., Abelmann, A., Armand, L., 2005. Sea-surface temperature and sea ice distribution of the Southern Ocean at the EPILOG Last Glacial Maximum-a circum-Antarctic view based on siliceous microfossil records. Quat. Sci. Rev. 24, 869-896.

Gersonde, R., Zielinski, U., 2000. The reconstruction of late Quaternary Antarctic sea-ice distribution - the use of diatoms as a proxy for sea-ice. Palaeogeogr. Palaeoclimatol. Palaeoecol. 162, 263-286.

Gibbard, P., Lewin, J., 2016. Partitioning the quaternary. Quat. Sci. Rev. 151, 127-139.

Gillikin, D.A., Lorrain, A., Meng, L., Dehairs, F., 2007. A large metabolic carbon contribution to the $13 \mathrm{C}$ record in marine aragonitic bivalve shells. Geochim. Cosmochim. Acta 71 (12), 2936-2946.

Glembocki, N.G., Williams, G.N., Góngora, M.E., Gagliardini, D.A., Orensanz, J.M., 2015. Synoptic oceanography of San Jorge Gulf (Argentina): a template for Patagonian red shrimp (Pleoticus muelleri) spatial dynamics. J. Sea Res. 95, 22-35.

Gottschalk, J., Skinner, L.C., Lippold, J., Vogel, H., Frank, N., Jaccard, S.L., Waelbroeck, 2016. Biological and physical controls in the Southern Ocean on past millennial-scale atmospheric $\mathrm{CO} 2$ changes. Nature Communications 7, 11539. www.nature.com/ naturecommunications https://doi.org/10.1038/ncomms11539.

Govin, A., Capron, E., Tzedakis, P.C., Verheyden, S., Ghaleb, B., Hillaire-Marcel, C., StOnge, G., Stoner, J.S., Bassinot, F., Bazin, L., Blunier, T., Combourieu-Nebout, N., El Ouahabi, A., Genty, D., Gersonde, R., Jimenez-Amat, P., Landais, A., Martrat, B., Masson-Delmotte, V., Parrenin, F., Seidenkrantz, M.-S., Veres, D., Waelbroeck, C., Zahn, R., 2015. Sequence of events from the onset to the demise of the Last Interglacial: evaluating strengths and limitations of chronologies used in climatic archives. Quat. Sci. Rev. 129, 1-36.

Graham, R.M., De Boer, A.M., van Sebille, E., Kohfeld, K.E., Schlosser, C., 2015. Inferring source regions and supply mechanisms of iron in the Southern Ocean from satellite chlorophyll data. Deep-Sea Research I 104, 9-25.

Gruber, N., 2015. Carbon at the coastal interface. Nature 517, 148-149.

Guerrero, R.A., Piola, A.R., 1997. Masas de Agua en la Plataforma Continental. In: Boschi, E.E. (Ed.), El mar Argentino y sus recursos pesqueros Tomo 1. INIDEP, vol. 998. pp. $107-118$.

Hansen, J., Sato, M., Hearty, P., Ruedy, R., Kelley, M., Masson-Delmotte, V., Russell, G., Tselioudis, G., Cao, J., Rignot, E., Velicogna, I., Tormey, B., Donovan, B., Kandiano, E., von Schuckmann, K., Kharecha, P., Legrande, A.N., Bauer, M., Lo, K.-W., 2016. Ice melt, sea level rise and superstorms: evidence from paleoclimate data, climate modeling, and modern observations that $2^{\circ} \mathrm{C}$ global warming could be dangerous. Atmos. Chem. Phys. 16, 3761-3812. https://doi.org/10.5194/acp-16-3761-2016.

Harley, C.D., Randall, H.A., Hultgren, K.M., Miner, B.G., Sorte, C.J., Thornber, C.S., Rodriguez, L.F., Tomanek, L., Williams, S.L., 2006. The impacts of climate change in coastal marine systems. Ecol. Lett. 9, 238-241.

Hartin, C., 2012. Subantarctic mode and antarctic intermediate water during the present and last glacial maximum. Open Access Dissertations 866. https:// scholarlyrepository.miami.edu/oa_dissertations/866.
Hartin, C.A., Fine, R.A., Sloyan, B.M., Talley, L.D., Chereskin, T.K., Happell, J., 2011. Formation rates of Subantarctic mode water and Antarctic intermediate water within the South Pacific. Deep Sea Res. Part I 58, 524-534.

Head, M., Aubry, M.-P., Walker, M., Miller, K., Pratt, B., 2017. A case for formalizing subseries (subepochs) of the Cenozoic Era. IUGS Episodes 40, 1.

Hearty, P.J., Hollin, J.T., Neumann, A.C., O'Leary, M.J., McCulloche, M., 2007. Globa sea-level fluctuations during the Last Interglaciation (MIS 5e). Quat. Sci. Rev. 26, 2090-2112.

Henley, Sian F., Turena, Robyn E., Annett, Amber L., Fallick, Anthony E., Meredith, Michael P., Venables, Hugh J., Clarke, Andrew, Ganeshram, Raja S., 2017. Macronutrient supply, uptake and recycling in the coastal ocean of the west Antarctic Peninsula. Deep Sea Research II: Topical Studies in Oceanography 139, 58-76. https://doi.org/10.1016/j.dsr2.2016.10.003.

Hodell, D.A., Channell, J.E.T., 2016. Mode transitions in Northern Hemisphere glaciation: co-evolution of millennial and orbital variability in Quaternary climate. Clim. Past 12, 1805-1828. https://doi.org/10.5194/cp-12-1805-2016.

Hodell, D.A., Gersonde, R., Blum, P., 2002. Leg 177 synthesis: insights into Southern Ocean paleoceanography on tectonic to millennial timescales. In: Gersonde, R., Hodell, D.A., Blum, P. (Eds.), Proceedings of the Ocean Drilling Program, Scientific Results. vol. 177.

Hodell, D.A., Venz, K.A., Charles, C.D., Ninnemann, U.S., 2003. Pleistocene vertical carbon isotope and carbonate gradients in the South Atlantic sector of the Southern Ocean. Geochem. Geophys. Geosyst. 4 (1), 1004. https://doi.org/10.1029/ 2002 GC000367.

Howe, J.N.W., Piotrowski, A.M., Oppo, D.W., Huang, K.-F., Mulitza, S., Chiessi, C.M., Blusztajn, J., 2016. Antarctic intermediate water circulation in the South Atlantic over the past 25,000 years. Paleoceanography 31, 1302-1314. https://doi.org/10. 1002/2016PA002975.

Isla, I., Schnack, E., 2016. Sea level changes during marine isotopic stage 3 (MIS 3) in Argentina. Chapter p. 147-154. In: Gasparini, G., Rabassa, J., Deschamps, C., Tonni, E. (Eds.), 2016: Marine Isotope Stage 3 in Southern South America, 60 ka B.P. to 30 ka B.P. Springer Earth System Sciences.

Ito, T., Bracco, A., Deutsch, C., Frenzel, H., Long, M., Takano, Y., 2015. Sustained growth of the Southern Ocean carbon storage in a warming climate. Geophysical Research Letters 42. https://doi.org/10.1002/2015GL064320.

Jones, D.S., 1983. Sclerochronology: reading the record of the molluscan shell. Am. Sci. 71, 384-391.

Jong, J., Schoemann, V., Lannuzel, D., Peter Croot, P., de Baar, H., Tison, J.-L., 2012. Natural iron fertilization of the Atlantic sector of the Southern Ocean by continental shelf sources of the Antarctic Peninsula. J. Geophys. Res. 117, G01029. https://doi. org/10.1029/2011JG001679.

Kahl, L.C., Bianchi, A.A., Osiroff, A.P., Ruiz Pino, A., Piola, A.R., 2017. Distribution of seaair CO2 fluxes in the Patagonian Sea: seasonal, biological and thermal effects. Cont. Shelf Res. 143, 18-28.

Kaiser, J., Lamy, F., Hebbeln, D., 2005. A 70-kyr sea surface temperature record off southern Chile (Ocean Drilling Program Site 1233). Paleoceanography 20, PA4009. https://doi.org/10.1029/2005PA001146.

Kämpf, J., Chapman, P., 2017. Upwelling systems of the world, chapter 2. In: The Functioning of Coastal Upwelling Systems. Springer. https://doi.org/10.1007/978-3319-42524-5_2.

Kanfoush, S.L., Hodell, D.A., Charles, C.D., Guilderson, T.P., Mortyn, G., Ninnemann, U.S., 2000. Millennial-scale instability of the Antarctic ice sheet during the last glaciation. Science 288 (5472), 1815-1819. https://doi.org/10.1126/science.288.5472. 1815.

Kaplan, M.R., Schaefer, J.M., Strelin, J.A., Denton, G.H., Anderson, R.F., Vandergoes, M.J., Finkel, R.C., Schwartz, R., Travis, H.S.G., Garcia, J.L., Martini, M.A., Nielsen, S.H.H., 2016. Patagonian and southern South Atlantic view of Holocene climate. Quat. Sci. Rev. 141, 112-125.

Kilian, R., Lamy, F., 2012. A review of Glacial and Holocene paleoclimate records from southernmost Patagonia (49-55'S). Quat. Sci. Rev. 53, 1-23.

Koubbi, P., De Broyer, C., Griffiths, H.J., Raymond, B., d'Udekem d'Acoz, C., Van de Putte, A.P., Danis, B., David, B., Grant, S., Gutt, J., Held, C., Hosie, G., Huettmann, F., Post, A., Ropert-Coudert, Y., Stoddart, M., Swadling, K.M., Wadley, V., 2014. Present and future of southern ocean biogeography. In: De Broyer, C., Koubbi, P., Griffiths, H.J., Raymond, B., Udekem d'Acoz, C.D'. (Eds.), Biogeographic Atlas of the Southern Ocean. Scientific Committee on Antarctic Research, Cambridge, pp. 470-475.

Krantz, D.E., Williams, D.F., Jones, D.S., 1987. Ecological and paleoenvironmental information using stable isotope profiles from living and fossil mollusks. Palaeogeogr. Palaeoclimatol. Palaeoecol. 58, 249-266.

Lamy, F., Kaiser, J., Ninnemann, U., Hebbeln, D., Arz, H.W., Stoner, J., 2004. Antarctic timing of surface water changes off Chile and patagonian ice sheet response. Science 304, 1959-1962. https://doi.org/10.1126/science.1097863.

Lartaud, F., Emmanuel, L., de Rafelis, M., Pouvreau, S., Renard, M., 2010. Influence of food supply on the $\delta 13 \mathrm{C}$ signature of mollusc shells: implications for palaeoenvironmental reconstitutions. Geo-Mar. Lett. 30 (1), 23-34. https://doi.org/10.1007 s00367-009-0148-4.

Lazareth, C., Lasne, G., Ortlieb, L., 2006. Growth anomalies in Protothaca thaca (Mollusca, Veneridae) shells as markers of ENSO conditions. Clim. Res. 30, 263-269.

Lessa, D.V.O., Santos, T. P. Venancio, I.M., Albuquerque, A.L.S. 2017. Offshore Expansion of the Brazilian Coastal Upwelling Zones During Marine Isotope Stage 5 Global and Planetary Change. 158. pp. 13-20.

Lisiecki, L.E., Raymo, M.E., 2005. A Pliocene-Pleistocene stack of 57 globally distributed benthic $\delta 180$ records. Paleoceanography 20, PA1003. https://doi.org/10.1029/ 2004PA001071.

Lisiecki, L.E., Raymo, M.E., Curry, W.B., 2008. Atlantic overturning responses to Late Pleistocene climate forcings. Nature 456, 85-88. https://doi.org/10.1038/ 
nature07425.

López, B.A., Macaya, E.C., Tala, F., Tellier, F., Thiel, M., 2017. The variable routes of rafting: stranding dynamics of floating bull-kelp Durvillaea antarctica (Fucales, Phaeophyceae) on beaches in the SE Pacific. J. Phycol. 53, 70-84. https://doi.org/10. 1111/jpy.12479.

Lorrain, A., Paulet, Y.-M., Chauvaud, L., Dunbar, R., Mucciarone, D., Fontugne, M., 2004. $\delta 13 \mathrm{C}$ variation in scallop shells: increasing metabolic carbon contribution with body size? Geochim. Cosmochim. Acta 68, 3509-3519.

Makou, M.C., Oppo, D.W., Curry, W.B., 2010. South Atlantic intermediate water mass geometry for the last glacial maximum from foraminiferal Cd/Ca. Paleoceanography 25, PA4101. https://doi.org/10.1029/2010PA001962.

Maksym, T., Stammerjohn, S.E., Ackley, S., Massom, R., 2012. Antarctic sea ice-A polar opposite? Oceanography 25 (3), 140-151. https://doi.org/10.5670/oceanog. 2012.88.

Marshall, J., Speer, K., 2012. Closure of the meridional overturning circulation through Southern Ocean upwelling. Nat. Geosci. https://doi.org/10.1038/NGEO1391.

Martínez, O.A., Kutschker, A., 2011. The 'Rodados Patagónicos' (Patagonian shingle formation) of eastern Patagonia: environmental conditions of gravel sedimentation. Biol. J. Linn. Soc. 103 (2), 336-345. https://doi.org/10.1111/j.1095-8312.2011. 01651.x.

Maslin, M.A., Swann, G.E.A., 2006. Isotopes in marine sediments. In: Leng, M.J. (Ed.), Isotopes in Palaeoenvironmental Research. Developments in Paleoenvironmental Research 10. Springer, pp. 227-290 Chapter 6.

McConnaughey, T.A., Gillikin, D., 2008. Carbon isotopes in mollusk shell carbonates Geo-Mar. Lett. 28 (5-6), 287-299.

Medina, R., Aguirre, M., Codignotto, J., Richiano, S., Mormeneo, L., 2014. Geoformas, Malacofauna Y Evolución Costera Durante El Holoceno En Ensenada Ferrer (Santa Cruz, Patagonia, Argentina). Revista Asociación Geológica Argentina 71 (1), 69-81 (ISSN impreso 0004-4822-ISSN en línea 1851-8249).

Moreno, P., Vilanova, I., Villa-Martínez, R., Dunbar, R., Mucciarone, D., Kaplan, M., Garreaud, R., Rojas, M., Moy, C., De Pol-Holz, R., Lambert, F., 2018. Onset and evolution of southern annular mode-like changes at centennial timescale. Nature Scientific Reports 8, 3458. https://doi.org/10.1038/s41598-018-21836-6.

Morrison, A.K., Frölicher, T.L., Sarmiento, J.L., 2015. Upwelling in the Southern Ocean. Physics Today 68 (1), 27. https://doi.org/10.1063/PT.3.2654.

Mouzo, F., 2014. Edad Del Golfo San Matías, Plataforma Continental Argentina Y La Estratigrafía En El Gran Bajo De San Antonio, Provincia De Río Negro. Rev. Asoc. Geol. Argent. 71 (1), 125-138.

Muller-Karger, F.E., Piola, A., Verheye, H.M., O'Brien, T.D., Lorenzoni, L., 2017. South Atlantic Ocean. In: O'Brien, T.D., Lorenzoni, L., Isensee, K., Valdés, L. (Eds.), What are Marine Ecological Time Series Telling Us About the Ocean? A Status Report. IOCUNESCO, pp. 83-96 (IOC Technical Series, No. 129. 297 pp).

Nace, T., Baker, P., Dwyer, G., Silva, C., Rigsby, C., Burns, S., Giosan, L., Otto-Bliesner, B., Liu, Z., Zhu, J., 2014. The role of North Brazil Current transport in the paleoclimate of the Brazilian Nordeste margin and paleoceanography of the western tropical Atlantic during the late Quaternary. Palaeogeogr. Palaeoclimatol. Palaeoecol. 415, 3-13.

Nagai, R., de Mello e Sousa, S., Lourenço, R., Caruso Bícego, M., de Mahiques, M., 2010. Brazilian Journal of Oceanography 58, 31-41 (special issue, IGCP526).

O'Leary, M.J., Hearty, P.J., Thompson, W.G., Raymo, M.E., Mitrovica, J.X., Webster, J.M., 2013. Ice sheet collapse following a prolonged period of stable sea level during the last interglacial. Nat. Geosci. 6, 796-800.

Olguín-Salinas, H.F., Brandini, F., Boltovskoy, D., 2015. Latitudinal patterns and interannual variations of spring phytoplankton in relation to hydrographic conditions of the southwestern Atlantic Ocean ( $34^{\circ}-62^{\circ}$ S). Helgol. Mar. Res. 69, 177-192.

O'Malley, R.T., Behrenfeld, M.J., Siegel, D.A., Maritorena, S., 2009. Global ocean phytoplankton. In: state of the climate in 2009. Bull. of Am. Meteorol. Soc. 91 (7), S75-S78.

Ortlieb, L., Díaz, A., Guzmán, N., 1996. A warm interglacial episode during Oxygen Isotope Stage 11 in Northern Chile. Quat. Sci. Rev. 15, 857-871.

Otto-Bliesner, B., Brady, E., Clauzet, G., Tomas, R., Levis, S., Kothavala, Z., 2006. Last glacial maximum and holocene climate in CCSM3. J. Clim. 19, 2526-2544.

Pahnke, K., Zahn, R., 2005. Southern Hemisphere Water Mass Conversion Linked with North Atlantic Climate Variability.

Palma, E., Matano, R., Piola, A., 2004a. A numerical study of the Southwestern Atlantic Shelf circulation: Barotropic response to tidal and wind forcing. J. Geophys. Res. 109 (C8), 1-17.

Palma, E., Matano, R., Piola, A., 2008. A numerical study of the Southwestern Atlantic Shelf circulation: Stratified ocean response to local and offshore forcing. J. Geophys. Res. 113, C11010. https://doi.org/10.1029/2007JC004720.

Palma, E., Matano, R., Piola, A., Sitz, L., 2004b. A comparison of the circulation patterns over the Southwestern Atlantic Shelf driven by different wind stress climatologies. Geophys. Res. Lett. 31 (L24303), 2004. https://doi.org/10.1029/2004GL021068.

Panassa, E., Santana-Casiano, J.M., González-Dávila, M., Hoppema, M., vanHeuven, S.M., Völker, C., Wolf-Gladrow, D., Hauck, J., 2018. Variability of nutrients and carbon dioxide in the Antarctic IntermediateWater between 1990 and 2014. Ocean Dyn. https://doi.org/10.1007/s10236-018-1131-2.

Paparazzo, F., Bianucci, L., Schloss, I., Almandoz, G., Solís, M., Esteves, J., 2010. Crossfrontal distribution of inorganic nutrients and chlorophyll- $a$ on the Patagonian Continental Shelf of Argentina during summer and fall. Rev. Biol. Mar. Oceanogr. 45, 107-119.

Paparazzo, F., Williams, G.N., Pisoni, J.P., Solís, M., Esteves, J.L., Varela, D.E., 2017. Linking phytoplankton nitrogen uptake, macronutrients and chlorophyll-a in SW Atlantic waters: The case of the Gulf of San Jorge. Argentina. Journal of Marine Systems 172. https://doi.org/10.1016/j.jmarsys.2017.02.007.

Paparazzo, F.E., Alder, V.A., Schloss, I.R., Bianchi, A., Esteves, J.L., 2016. Spatial and temporal trends in the distribution of macronutrients in surface waters of the Drake
Passage. Ecol. Austral 26 (1), 27-39.

Paparazzo, F.E., Esteves, J.L., 2018. Surface macronutrient dynamics of the Drake Passage and the Argentine Sea. In: Hoffmeyer, M.S. (Ed.), Plankton Ecology of the Southwestern Atlantic, https://doi.org/10.1007/978-3-319-77869-3_4.

Pappalardo, M., Aguirre, M., Bini, M., Consoloni, I., Fucks, E., Hellstrom, J., Isola, I., Ribolini, A., Zanchetta, G., 2015. Coastal landscape evolution and sea-level change: a case study from Central Patagonia (Argentina). Z. Geomorphol. 59 (2), 145-172. ISSN 0372-8854. https://doi.org/10.1127/0372-8854/2014/0142.

Parker, G., Paterlini, M., Violante, R., 1997. El fondo marino. In: El Mar Argentino y sus recursos pesqueros. 1. Instituto Nacional de Investigación y Desarrollo Pesquero, pp. 65-88.

Past Interglacials Working Group of PAGES, 2016. Interglacials of the last 800,000 years. Rev. Geophys. 54, 162-219. https://doi.org/10.1002/2015RG000482.

Peterson, R.G., Stramma, L., 1991. Upper-level circulation in the South Atlantic Ocean. Prog. Oceanogr. 26, 1-73.

Petró, S., Gómez Pivel, M., Coimbra, J.-C., Pimentel Mizusak, A., 2016. Paleoceanographic changes through the last $130 \mathrm{Ka}$ in the Western South Atlantic based on Planktonic Foraminifera. Rev. Bras. Paleontol. 19 (1), 3-14.

Piola, A.R., Falabella, V., 2009. El Mar Patagónico. In: Falabella, V., Campagna, C., Croxall, J. (Eds.), Atlas del Mar Patagónico. Especies y espacios Buenos Aires, Wildlife Conservation Society and BirdLife International, pp. 54-76.

Piola, A.R., Martínez Avellaneda, N., Guerrero, R.A., Jardón, F.P., Palma, E.D., Romero, S.I., 2010. Malvinas slope water intrusions on the northern Patagonia continental shelf. Ocean Sci. 6 (345-359) (1812-0806).

Piola, A.R., Matano, R.P., 2017. Ocean currents: Atlantic Western boundary-Brazil current/Falkland (Malvinas) current. In: Reference Module in Earth Systems and Environmental Sciences. Elsevier. https://doi.org/10.1016/B978-0-12-409548-9. 10541-X.

Piola, A.R., Palma, E.D., Bianchi, A.A., Castro, B.M., Dottori, M., Guerrero, R.A., Marrari, M., Matano, R.P., Möller Jr., O.O., Saraceno, M., 2018. Physical oceanography of the SW Atlantic shelf: a review. In: Hoffmeyer, M.S. (Ed.), Plankton Ecology of the Southwestern Atlantic, https://doi.org/10.1007/978-3-319-77869-3_2.

Piola, A.R., Rivas, A.L., 1997. Corrientes en la plataforma continental. In: Boschi, E.E. (Ed.), El Mar Argentino y sus recursos pesqueros. Instituto Nacional de Investigación y Desarrollo Pesquero. Mar del Plata, pp. 119-132.

Ponce, J., Rabassa, J., Coronato, A., Borromei, A., 2011. Palaeogeographical evolution of the Atlantic coast of Pampa and Patagonia from the last glacial maximum to the Middle Holocene. Biol. J. Linn. Soc. 103, 363-379.

Quade, J., Kaplan, M.R., 2017. Lake-level stratigraphy and geochronology revisited at Lago (Lake) Cardiel, Argentina, and changes in the Southern Hemispheric Westerlies over the last 25 ka. Quat. Sci. Rev. 177, 173-188.

Ribolini, A., Aguirre, M., Baneschi, I., Consoloni, I., 2011. Holocene beach ridges and coastal evolution in the Cabo Raso Bay (Atlantic Patagonian Coast, Argentina). J. Coast. Res. 27, 973-983.

Richiano, S., Aguirre, M., Farinati, E., 2013. Bioerosion structures in Quaternary marine mollusks from Argentina. In: Netto, R., Carmona, N., Tognoli, F. (Eds.), Ichnology of Latin America. Sociedade Brasileira de Paleontologia, Monografias, vol. 2. pp. 159-177.

Richiano, S., Aguirre, M., Farinati, E., Davies, K., Castellanos, I., 2015. Bioerosion structures in Crepidula (Mollusca, Gastropoda) as indicators of latitudinal palaeoenvironmental changes: example from the marine Quaternary of Argentina. Palaeogeogr. Palaeoclimatol. Palaeoecol. 439, 63-78.

Richiano, S., Aguirre, M.L., Farinati, E., Davies, K., Castellanos, I., 2017. Do coastal fronts influence bioerosion patterns along Patagonia? Late Quaternary ichnological tools from Golfo San Jorge. J. Mar. Syst. 176, 38-53.

Rivas, A., Pisoni, J., 2010. Identification, characteristics and seasonal evolution of surface thermal fronts in the Argentinean Continental Shelf. J. Mar. Syst. 79 (1-2), 134-143.

Roberts, J., Gottschalk, J., Skinner, L., Peck, V., Kender, S., Elderfield, H., Waelbroeck, C., Vázquez Rivera, N., Hodell, D., 2017. Evolution of South Atlantic density and chemical stratification across the last deglaciation. PNAS 113 (3), 513-519.

Rohling, E.J., 2013. Oxygen isotope composition of seawater. In: Elias, S.A. (Ed.), The Encyclopedia of Quaternary Science 2. Elsevier, Amsterdam, pp. 915-922.

Romero, S., 2008. Estimaciones satelitales de clorofila y los frentes oceánicos del Atlántico sudoccidental. PhD thesis unpublish. Buenos Aires University (211 pp).

Romero, S., Piola, A., Charo, M., Garcia, C., 2006. Chlorophyll- a variability off Patagonia based on SeaWiFS data. J. Geophys. Res. 111 (C5), 1-11.

Rubo, S., Aguirre, M., Richiano, S., Medina, R., Schöne, B.R., 2018. Leukoma (Protothaca) antiqua (Bivalvia) - a high-resolution marine paleoclimate archive for southern South America? Palaeogeogr., Palaeoecol., Palaeoclimatol. 505, 398-409. https://doi.org/ 10.17632/sz2v8ztb38.1.

Ruiz-Etcheverry, L.A., Saraceno, M., Piola, A.R., Strub, P.T., 2016. Sea level anomaly on the Patagonian continental shelf: trends, annual patterns and geostrophic flows. J. of Geophys. Res.: Oceans. https://doi.org/10.1002/2015JC01126.

Sachs, J.P., Anderson, R.F., 2005. Increased productivity in the subantarctic ocean during Heinrich events. Lett. Nat. 434, 1118-1121. www.nature.com/nature.

Saunders, K.M., Roberts, S.J., Perren, B., Butz, C., Sime, L., Davies, S., Nieuwenhuyze, W.V., Grosjean, M., Hodgson, D.A., 2018. Holocene dynamics of the Southern Hemisphere westerly winds and possible links to CO2 outgassing. Nat. Geosci. 11, 650-655. www.nature.com/naturegeoscience.

Schöne, B.R., Dunca, E., Fiebig, J., Pfeiffer, M., 2005. Mutvei's solution: an ideal agent for resolvingmicrogrowth structures of biogenic carbonates. Palaeogeogr Palaeoclimatol. Palaeoecol. 228 (1-2), 149-166.

Schöne, B.R., Surge, D.M., 2012. Bivalve Sclerochronology and Geochemistry. Part N, Revised. vol. 1. pp. 1-24 Chapter 14: Treatise Online 46. (8 fig).

Shepherd, A., Fricker, H.A., Farrell, S.L., 2018. Trends and connections across the Antarctic cryosphere. Nature 558, 223-232. https://doi.org/10.1038/s41586-018- 
0171-6.

Sikes, E., Allen, K., Lund, D., 2017. Enhanced $\delta 13 \mathrm{C}$ and $\delta 180$ differences between the South Atlantic and South Pacific During the last glaciation: the deep gateway hypothesis. Paleoceanography 1-18. https://doi.org/10.1002/2017PA003118.

de Souza, A.R.Q., Kerr, R., de Azevedo, J.L.L., 2018. On the influence of Subtropical Mode Water on the South Atlantic Ocean. J. Mar. Syst. 185, 13-24.

Tala, F., Velásquez, M., Mansill, A., Macaya, E.C., Thiel, M., 2016. Latitudinal and seasonal effects on short-term acclimation of floating kelp species from the South-East Pacific. J. Exp. Mar. Biol. Ecol. 483, 31-41.

Talley, L.D., 2013. Closure of the global overturning circulation through the Indian, Pacific, and Southern Oceans: schematics and transports. Oceanography 26 (1), 80-97. https://doi.org/10.5670/oceanog.2013.07.

Toggweiler, J.R., 2009. Shifting Westerlies to shift after the last glacial period ? Science 323, 1434-1435. www.sciencemag.org.

Toggweiler, J.R., Russell, J.L., 2008. Ocean circulation in a warming climate. Nature 451, 286-288.

Toggweiler, J.R., Russell, J.L., Carson, S.R., 2006. Midlatitude westerlies, atmospheric $\mathrm{CO} 2$, and climate change during the ice ages. Paleoceanography 21, PA2005. https:// doi.org/10.1029/2005PA001154.

Toggweiler, J.R., Samuels, B., 1995. Effect of Drake Passage on the global thermohaline circulation. Deep-Sea Res. I 42 (4), 477-500.

Turney, C., Jones, R., Phipps, S., Thomas, Z., Hogg, A., Kershaw, A., Fogwill, C., Palmer, J., Ramsey, C., Adolphi, F., Muscheler, R., Hughen, K., Staff, R., Grosvenor, M., Golledge, N., Rasmussen, S., Hutchinson, D., Haberle, S., Lorrey, A., Boswijk, G. Cooper, A., 2017. Rapid global ocean-atmosphere response to Southern Ocean freshening during the last glacial. Nat. Commun. 8, 520. https://doi.org/10.1038/ s41467-017-00577-6. www.nature.com/naturecommunications.

Voigt, I., Chiessi, C.M., Piola, A.R., Henrich, R., 2016. Holocene changes in Antarctic IntermediateWater flow strength in the Southwest Atlantic. Palaeogeogr. Palaeoclimatol. Palaeoecol. 463 (2016), 60-67.

Voigt, I., Chiessi, C.M., Prange, M., Mulitza, S., Groeneveld, J., Varma, V., Henrich, R. 2015. Holocene shifts of the southern westerlies across the South Atlantic Paleoceanography 30, 39-51. https://doi.org/10.1002/2014PA002677.

WAIS Divide Project Members, 2015. Precise interpolar phasing of abrupt climate change during the last ice age. Nature 520, 661-665.
Walker, M., Head, M., Lowe, J., Berkelhammer, M., Björck, S., Cheng, H., Cwynar, L., Fisher, D., Gkinis, V., Long, A., Newnham, R., Rasmussen, S., Weiss, H., 2019. Subdividing the Holocene Series/Epoch: formalization of stages/ages and subseries/ subepochs, and designation of GSSPs and auxiliary stratotypes. J. Quat. Sci. 34 (3), 173-186.

Walther, G.R., Post, E., Convey, P., Menzel, A., Parmesank, C., Beebee, T.J.C., Fromentin, J.-M., Hoegh-Guldberg, O., Bairlein, F., 2002. Ecological responses to recent climate change. Nature 416. www.nature.com.

Weber, M.E., Clark, P.U., Kuhn, G., Timmermann, A., Sprenk, D., Gladstone, R., Zhang, X., Lohmann, G., Menviel, L., Chikamoto, M.O., Friedrich, T., Ohlwein, C., 2014. Millennial-scale variability in Antarctic ice-sheet discharge during the last deglaciation. Nature 510, 134-138.

Wefer, G., Mulitza, S., Ratmeyer, V. (Eds.), 2003. The South Atlantic in the Late Quaternary: Reconstruction of Material Budgets and Current Systems. Springer, Berlin, pp. 722.

Wiebe, P.H., Atkinson, A., O'Brien, T.D., Thompson, P.A., Hosie, G., Lorenzoni, L., Meredith, M., et al., 2017. Southern Ocean. In: O'Brien, T.D., Lorenzoni, L., Isensee, K., Valdés, L. (Eds.), What are Marine Ecological Time Series telling us about the ocean? A Status Report. IOC-UNESCO, pp. 97-112 (IOC Technical Series, No. 129. 297 pp).

Williams, P.W., McGlone, M., Neil, H., Zhao, J.-X., 2015. A review of New Zealand palaeoclimate from the Last Interglacial to the global Last Glacial Maximum. Quat. Sci. Rev. 110, 92-106.

Wingenter, O.W., Elliott, S.M., Blake, D.R., 2010. New directions: restoring the westerly winds in the Southern Hemisphere: climate's lever. Atmos. Environ. 44, 3866-3868.

Wolff, E.W., Fischer, H., et al., 2006. Southern Ocean sea-ice extent, productivity and iron flux over the past eight glacial cycles. Nature 440, 491-496.

Yao, W., Shil, J., Zhao, X., 2017. Freshening of Antarctic intermediate water in the South Atlantic Ocean in 2005-2014. Ocean Sci. 13 (521-530), 2017. https://doi.org/10. 5194/os-13-521-2017.

Yin, Q., Berger, A., 2015. Interglacial analogues of the Holocene and its natural near future. Quat. Sci. Rev. 120, 28-46.

Zachos, J., Pagani, M., Sloan, L., Thomas, E., Billups, K., 2001. Trends, rhythms, and aberrations in global climate 65 Ma to present. Science 292, 686-693. 